University of Nebraska - Lincoln

DigitalCommons@University of Nebraska - Lincoln

Risk mapping for sensitive species to underwater anthropogenic sound emissions: Model development and validation in two Mediterranean areas

\author{
Arianna Azzellino \\ University of Technology, arianna.azzellino@polimi.it \\ C. Lanfredi \\ University of Technology
}

A. D'Amico

Space and Naval Warfare Systems Center Pacific

G. Pavan

Università di Pavia

M. Podestà

Museum of Natural History of Milan

See next page for additional authors

Follow this and additional works at: https://digitalcommons.unl.edu/usnavyresearch

Azzellino, Arianna; Lanfredi, C.; D’Amico, A.; Pavan, G.; Podestà, M.; and Haun, J., "Risk mapping for sensitive species to underwater anthropogenic sound emissions: Model development and validation in two Mediterranean areas" (2011). U.S. Navy Research. 28.

https://digitalcommons.unl.edu/usnavyresearch/28

This Article is brought to you for free and open access by the U.S. Department of Defense at DigitalCommons@University of Nebraska - Lincoln. It has been accepted for inclusion in U.S. Navy Research by an authorized administrator of DigitalCommons@University of Nebraska - Lincoln. 


\section{Authors}

Arianna Azzellino, C. Lanfredi, A. D'Amico, G. Pavan, M. Podestà, and J. Haun 


\title{
Risk mapping for sensitive species to underwater anthropogenic sound emissions: Model development and validation in two Mediterranean areas
}

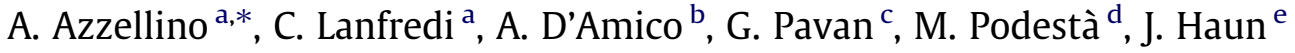 \\ a Politecnico di Milano, University of Technology, DIIAR Environmental Engineering Division, Piazza Leonardo da Vinci 32, 20133 Milano, Italy \\ ${ }^{\mathrm{b}}$ Space and Naval Warfare Systems Center Pacific, 53560 Hull Street, San Diego, CA 92152-5001, USA

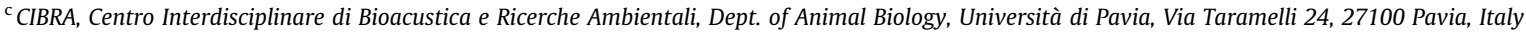 \\ ${ }^{\mathrm{d}}$ Museum of Natural History of Milan, Vertebrate Zoology Department, C.so Venezia 55, 20121 Milano, Italy \\ ${ }^{\text {e }}$ NATO Undersea Research Centre, V.le San Bartolomeo 400, 19126 La Spezia, Italy
}

\section{A R T I C L E I N F O}

\section{Keywords:}

Risk assessment

Habitat

Model validation

Cuvier's beaked whale

Noise impact

Mediterranean Sea

\begin{abstract}
A B S T R A C T
Recent observations of cetacean mass strandings, coincident with anthropogenic sounds emissions, have raised concerns on the potential environmental impact of underwater noise. Cuvier's beaked whale (Ziphius cavirostris) was reported in all the cited stranding events. Within the NATO Marine Mammal Risk Mitigation project (MMRM), multiple interdisciplinary sea trials have been conducted in the Mediterranean Sea with the objective of developing tools and procedures to mitigate the impact of underwater sound emissions. During these cruises, visual observations, passive acoustic detections and environmental data were collected. The aim of this study was to evaluate "a priori" predictions of Cuvier's beaked whale presence in the Alboran Sea, using models developed in the Ligurian Sea that employ bathymetric and chlorophyll features as predictors. The accuracy of these predictions was found adequate and elements are given to account for the uncertainties associated to the use of models developed in areas different from their calibration site.
\end{abstract}

(c) 2011 Elsevier Ltd. All rights reserved.

\section{Introduction}

Managing the environmental risks due to the anthropogenic noise in marine environments is still very far from being state of the art (Dolman et al., 2011 Papanicolopulu, 2011). Although extremely ambitious, the EU legislation, that has been adopted only recently, is still lacking in many aspects. The aim of the European Union's Marine Strategy (Directive, 2008 adopted in June 2008) is, in fact, to protect more effectively the marine environment across Europe from all the pressures derived by human activities. Article 3(8) of the Directive defines: “'pollution' means the direct or indirect introduction into the marine environment, as a result of human activity, of substances or energy, including human-induced marine underwater noise, which results or is likely to result in deleterious effects such as harm to living resources and marine ecosystems". In addition, marine underwater noise appears also in ANNEX I (i.e. Qualitative descriptors for determining good environmental status) as the "introduction of energy at levels that do not adversely affect the marine environment" and is listed in ANNEX III (i.e. indicative lists of characteristics, pressures and impacts) where underwater noise (e.g. from shipping, underwater acoustic equipment) is defined as a "physical disturbance". One of the biggest

\footnotetext{
* Corresponding author. Tel.: +39 02239964 31; fax: +39 0223996499.

E-mail address: arianna.azzellino@polimi.it (A. Azzellino).
}

challenges in regulating the effects of anthropogenic noise is the lack of knowledge of the characteristics and sound exposure levels that may pose risks to marine life. Although, there is increasing concern regarding the impact of underwater noise on fishes and marine invertebrates (DFO, 2004; Popper et al., 2004, 2005, 2007), to date most of the research has focused on marine mammals (i.e. mainly cetaceans and pinnipeds, Southall et al., 2007) and a few other vertebrates (i.e. sea turtles) (Klima et al., 1988; McCauley et al., 1999, 2000). Some high energy sound sources have been, in fact, correlated to mortality events of marine mammals, the majority of these involving atypical mass strandings of beaked whales (D'Amico et al., 2009; Evans and Miller, 2004; Freitas, 2004; Frantzis, 1998; Martín Martel, 2002; Martín et al., 2004; Parsons et al., 2008; Simmonds and Lopez-Jurado, 1991). Beaked whales represent one of the groups of large marine mammals whose behavior and ecology is largely unknown (MacLeod and Mitchell, 2006; MacLeod and D'Amico, 2006). Most of the available information about beaked whales was gleaned from beached animals, sometimes discovered far from the deep water habitats in which they lived (Heyning, 1989; MacLeod, 2000; Podestá et al., 2006). The knowledge about beaked whale ecology, particularly their dive patterns (Baird et al., 2006, 2008; Hobson and Martin, 1996; Hooker and Baird, 1999; Tyack et al., 2006) and acoustic behaviors (Aguilar de Soto et al., 2006; Frantzis et al., 2002; Johnson et al., 2004, 2006, 2007; Jones et al., 2008; 
Madsen et al., 2005, 2007; Pavan et al., 2009; Zimmer et al., 2005, 2008; Zimmer and Pavan, 2008) has been enhanced by recent studies.

The first detailed quantifications of the extreme diving capabilities of two species of beaked whales (Ziphius cavirostris and Mesoplodon densirostris) and their concurrent acoustic behavior has been provided only recently using data obtained from multisensor sound-and-orientation recording tags (DTAGs, Johnson and Tyack, 2003; Tyack et al., 2006). Reports of gas and fat emboli in beaked whales stranded during naval sonar exercises (Fernández et al., 2005) have led to the hypothesis that their diving behavior may make them especially vulnerable to decompression sickness (Wright et al., 2011; Zimmer and Tyack, 2007). Even though the overall knowledge about beaked whale biology is increasing with recent studies, the exact mechanisms by which anthropogenic sound production may affect beaked whales are still unclear (Cox et al., 2006; MacLeod and D'Amico, 2006; Parsons et al., 2008). According to D'Amico et al. (2009) the majority of beaked whale strandings do not apparently correlate in space and time with naval activities.

Notwithstanding, the sound sources that have been shown to be temporally and spatially coincident with beaked whale mass strandings are naval mid-frequency sonars $(2-10 \mathrm{kHz})$ and, to a lower extent, airgun arrays, both of which are widely used throughout the world for defense and geophysical exploration, respectively (Barlow and Gisiner, 2006).

Acoustic risk mitigation procedures and guidelines for these sound sources are being studied and developed by navies, administrations, and commercial companies (Barlow and Gisiner, 2006; JNCC, 2004; NURC, 2006; Pavan, 2006). The proposed mitigation practices are often based on perceived "common sense" rather than real knowledge of risks, and they are still largely untested. On the other hand, lower impact alternative technologies are to date not readily available.

Avoidance of beaked whale habitats could provide a straightforward means for reducing the potential effects of mid-frequency sonars and geophysical sound sources (Barlow and Gisiner, 2006). From the perspective of habitat avoidance, the key point is the ability to accurately predict regions where sensitive species are not present or present in low densities, thus minimizing exposure to anthropogenic noise. The determination of beaked whale habitat requirements and preferences by using validated habitat predictors can support environmental risk assessment frameworks by providing insight into areas where a population is present. Insight gained from tools that geospatially define beaked whale key habitat characteristics and estimate the probabilities of high or low density areas, can support risk management decisions (Harwood, 2000). A variety of statistical approaches are currently in use to model the spatial distribution of terrestrial and aquatic species (Guisan and Zimmermann, 2000). Only in very few occasions have these models been evaluated for their transferability to areas different from their calibration sites. The objective of this study is to evaluate the transferability of a habitat model developed for the Ligurian Sea area (northwestern Mediterranean Sea) applied a priori to another Mediterranean Sea area (e.g. the Alboran Sea (western Mediterranean Sea).

\section{Materials and methods}

The NURC Marine Mammal Risk Mitigation (hereinafter called MMRM) Project has conducted several interdisciplinary sea trials, typically in the late spring/summer season, in the northwestern Mediterranean Sea. The majority of these at sea trials, entitled SIRENA, were focused on the Ligurian Sea area (from 1999 to 2006). In 2008 the survey was moved to the Alboran Sea area, in the western Mediterranean Sea (Fig. 1).

\subsection{Study areas}

\subsubsection{Model development area}

The Ligurian Sea is a deep semi-enclosed Basin in the Northwest Mediterranean Sea, bordered by the coastlines of France and Italy. Water depths in the Ligurian Sea are deeper than $2000 \mathrm{~m}$.

The Ligurian Basin's general circulation is the combined result of two major currents, the Ligurian Current and the West Corsican Current (Millot, 1999). During part of the year, there is also the influence of water flowing from the Tyrrhenian Sea along the east coast of Corsica. When these water masses join together north of Corsica, they create a cyclonic pattern that moves in a southwest direction following the continental shelf, flowing between 50 and $250 \mathrm{~m}$. A frontal region is commonly found at the limit of the cold core of the cyclonic Ligurian Sea circulation and the warm waters moving parallel to it. Such phenomena are intermittently and seasonally reinforced by vertical mixing and coastal upwelling, generated by the prevailing north-westerly wind ('mistral'), which pumps deep nutrients and other organic substances contributed by rivers into the euphotic zone, where they fertilize growing phytoplankton populations (Arnau et al., 2004; Gonnella et al., 1977). Subsequent high levels of primary production support a conspicuous biomass that attracts various upper-trophic level predators, including cetaceans, into the area (Forcada et al., 1995, 1996; Gordon et al., 2000; Notarbartolo di Sciara, 2008). As such, this area was designated as the first "International Sanctuary for the Protection of Mediterranean Marine Mammals" also know as the "Pelagos Sanctuary" (Fig. 2a). All cetaceans regularly observed in the Mediterranean Sea, including seven species of odontocetes ( $\mathrm{Cu}-$ vier's beaked whale (Z. cavirostris), striped dolphin (Stenella coeruleoalba), Risso's dolphin (Grampus griseus), sperm whale (Physeter macrocephalus), long-finned pilot whale (Globicephala melas), common bottlenose dolphin (Tursiops truncatus), shortbeaked common dolphin (Delphinus delphis)) and only one species of mysticete, the fin whale (Balaenoptera physalus) are found in this region. The Gulf of Genoa in the Ligurian Sea was found to be a key area in the western Mediterranean Basin since Cuvier's beaked whales have been regularly observed at sea (Azzellino et al., 2008; D'Amico et al., 2003; Macleod and Mitchell, 2006; Moulins et al., 2007). The Gulf of Genoa is characterized by several canyons with very steep slope gradients extending from the shelf break to a depth of about $1200 \mathrm{~m}$. The Genoa canyon region (Fig. 2b) is the far northeastern portion of the Ligurian Sea Basin and it is a large submarine valley that forms a boundary for the predominant circulation. The Genoa canyon has its axis oriented northeast-southwest, with two main canyons present in the head. Directly east of this region is another large, wider canyon with a wide shelf to its south. There are also several seamounts. The western part of the valley has a steep slope to $1200 \mathrm{~m}$ and it is cut by several small canyons. To the southwest, the canyon faces the deep abyssal feedback plain. A study conducted on seawater samples collected from surface to $1000 \mathrm{~m}$ depth in the Genoa canyon (Misic and Fabiano, 2006) found an enhancement of primary biomass in the summer season driven probably by physical processes such as LiguroProvencal front dynamics, thus increasing the potential transfer of energy and materials to the other trophic levels. Moreover, the same authors found increases in ectoenzymatic activity in the mesopelagic layer that was linked to the presence of active microbial assemblages which was thought to enhance the recycling potential of the food web.

\subsubsection{Model evaluation area}

The Alboran Sea is located in the southwestern portion of the Mediterranean Sea, lying between Spain on the north and Morocco on the south (Fig. 3). The Strait of Gibraltar, which lies at the western end of the Alboran Sea, connects the Mediterranean Sea with 


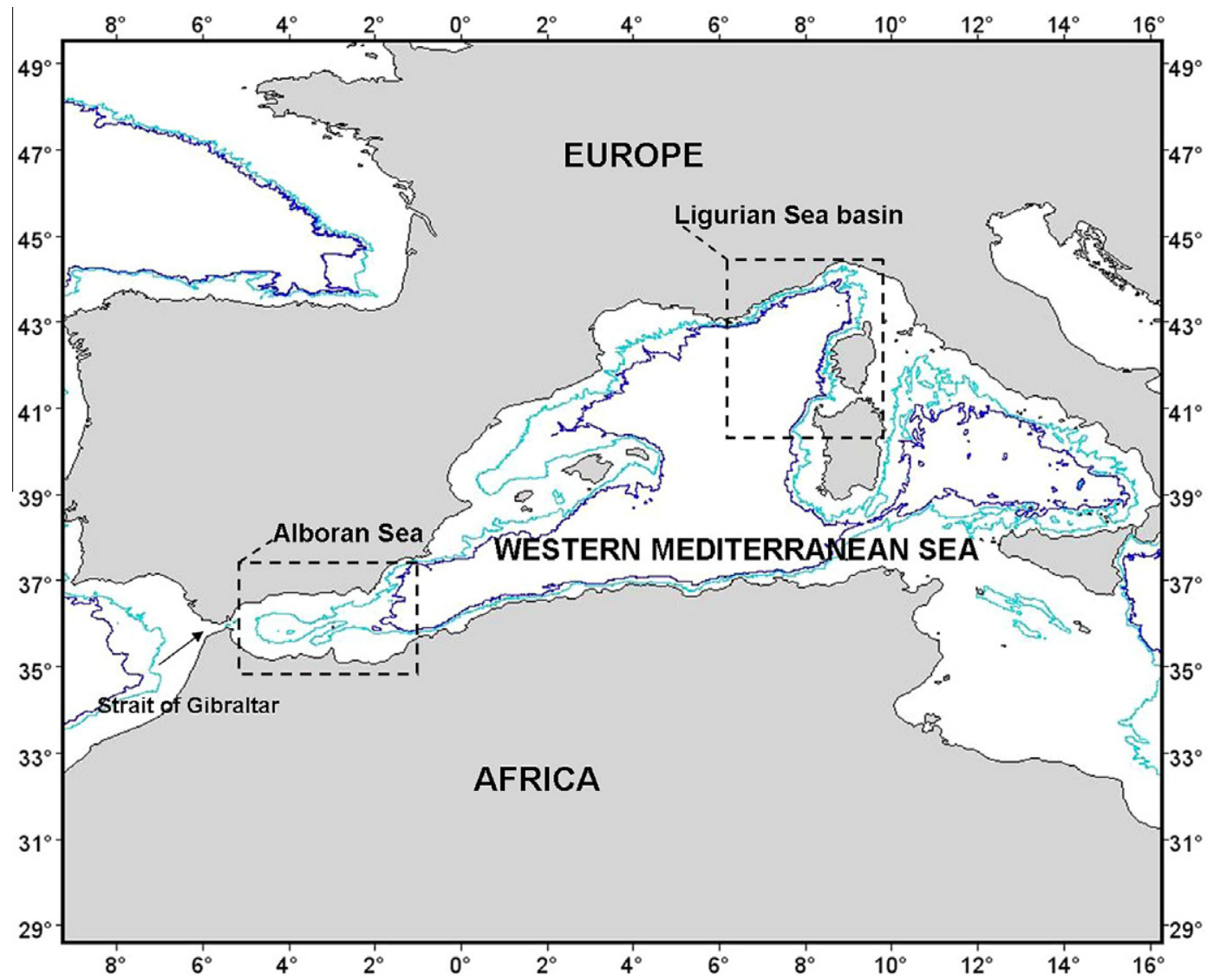

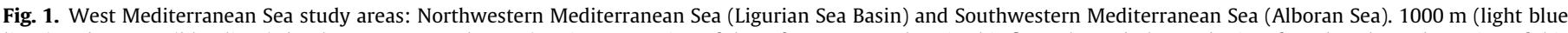

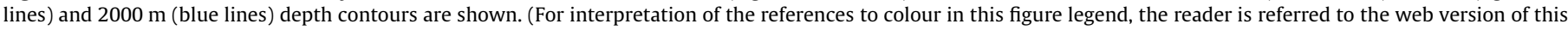
article.)

the Atlantic Ocean. Atlantic water (AW) enter the Mediterranean Sea as a surface flow through the Strait of Gibraltar, mixes with upwelled Mediterranean Intermediate Water (MIW), creating Modified Atlantic Water (MAW) which flows along the southern Spanish coast as a strong jet that initiates the formation of two anti cyclonic gyres within the Alboran Sea (the Eastern Alboran Gyre and the Western Alboran Gyre). As the MAW flows eastward along the Spanish coast to Almeria, it converges with resident Mediterranean waters (Tintoré et al., 1988). The subsequent deflection of MAW towards the Algerian coast forms a well defined frontal zone, the Almeria-Oran Front, along the eastern edge of the Eastern Alboran Gyre. This front extends to a depth of $200 \mathrm{~m}$ and has a width of approximately $35 \mathrm{~km}$ (Cheney and Doblar, 1982) and it is thought to be a permanent feature, although its position and intensity are controlled by the degree of development of the Eastern Alboran Gyre (Tintoré et al., 1988).

This circulation pattern is often referred as the hydrologic motor of the western Mediterranean playing an important role in the oceanography of the entire Mediterranean Sea and makes this area one of the most productive regions of the Mediterranean Basin (Rohling et al., 1995).

The Alboran Sea has a complex bottom topography with a very narrow abyssal plain characterized by depths generally lower than $2000 \mathrm{~m}$. The shelf edge area is characterized by a great variability of slopes, with steep escarpments, canyons, and volcanic mountains such as those giving rise to the Island of Alboran, located in the central part of the Alboran Sea Basin, $50 \mathrm{~km}$ north of the Moroccan coast and $90 \mathrm{~km}$ south of Spanish coast. This complex sea-floor topography serves to increase upwelling and concentrate productivity (Cañadas and Sagarminaga, 2000). Most of the available information on cetacean occurrence are related to studies conducted in the Spanish waters of the Alboran Sea (Cañadas et al., 2002, 2005; Cañadas and Sagarminaga, 2000). Many species of odontocete species commonly found in the Mediterranean Sea inhabit this area, such as common bottlenose dolphin, short-beaked common dolphin, striped dolphin, long-finned pilot whale, Risso's dolphin, sperm whale, Cuvier's beaked whale and one mysticete species, the fin whale. The Northern bottlenose whale (Hyperoodon ampullatus) has been sighted in this region by Cañadas et al., 2005. Cañadas and colleagues (Cañadas et al., 2002, 2005) identified beaked whale habitat preference in deep (i.e. around $1000 \mathrm{~m}$ depth) and steep areas between southern Almeria and north of the Island of Alboran. Acoustic detections of fin whale vocalizations were recorded south of Almeria in the winter 2007 (NovemberJanuary) which indicates whale presence in the area (Castellote et al., 2008). Because of this high biodiversity, the Spanish Mediterranean waters were proposed to become Areas of Special Interest for the Conservation of Cetaceans. The Strait of Gibraltar, the area south of Almeria and the Island of Alboran were proposed as Special Areas of Conservation (SAC) under the EU Habitats Directive. Both the inshore and offshore Mediterranean Spanish waters, including the three proposed SAC areas, were identified as Specially Protected Area of Mediterranean Importance (SPAMI) under the Barcelona Convention (Cañadas et al., 2005).

\subsection{Data collection}

\subsubsection{Ligurian Sea}

MMRM summer and late summer survey ship-based trials were conducted in 2001 (SIRENA '01), 2002 (SIRENA '02) and 2003 
(a)

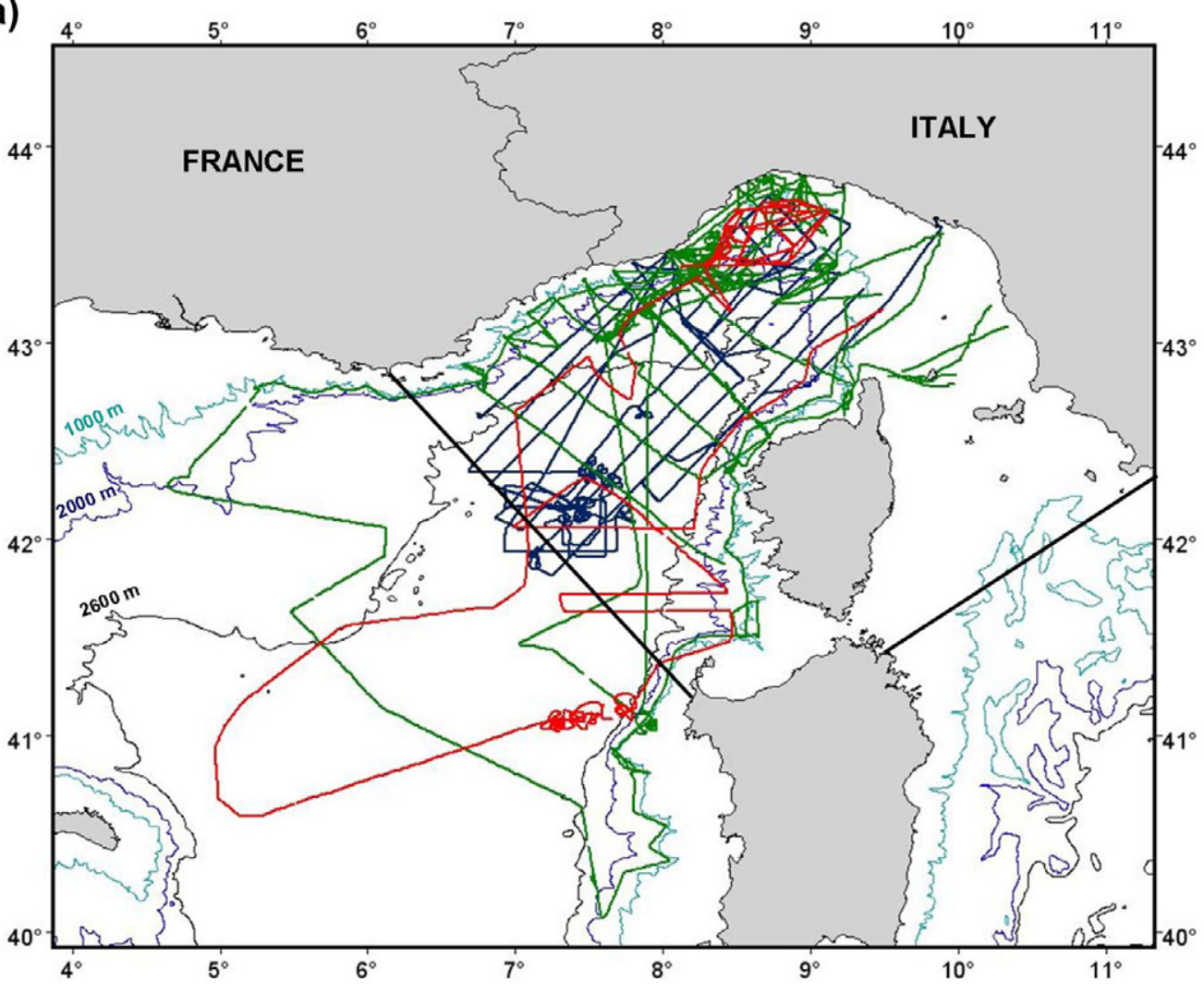

(b)

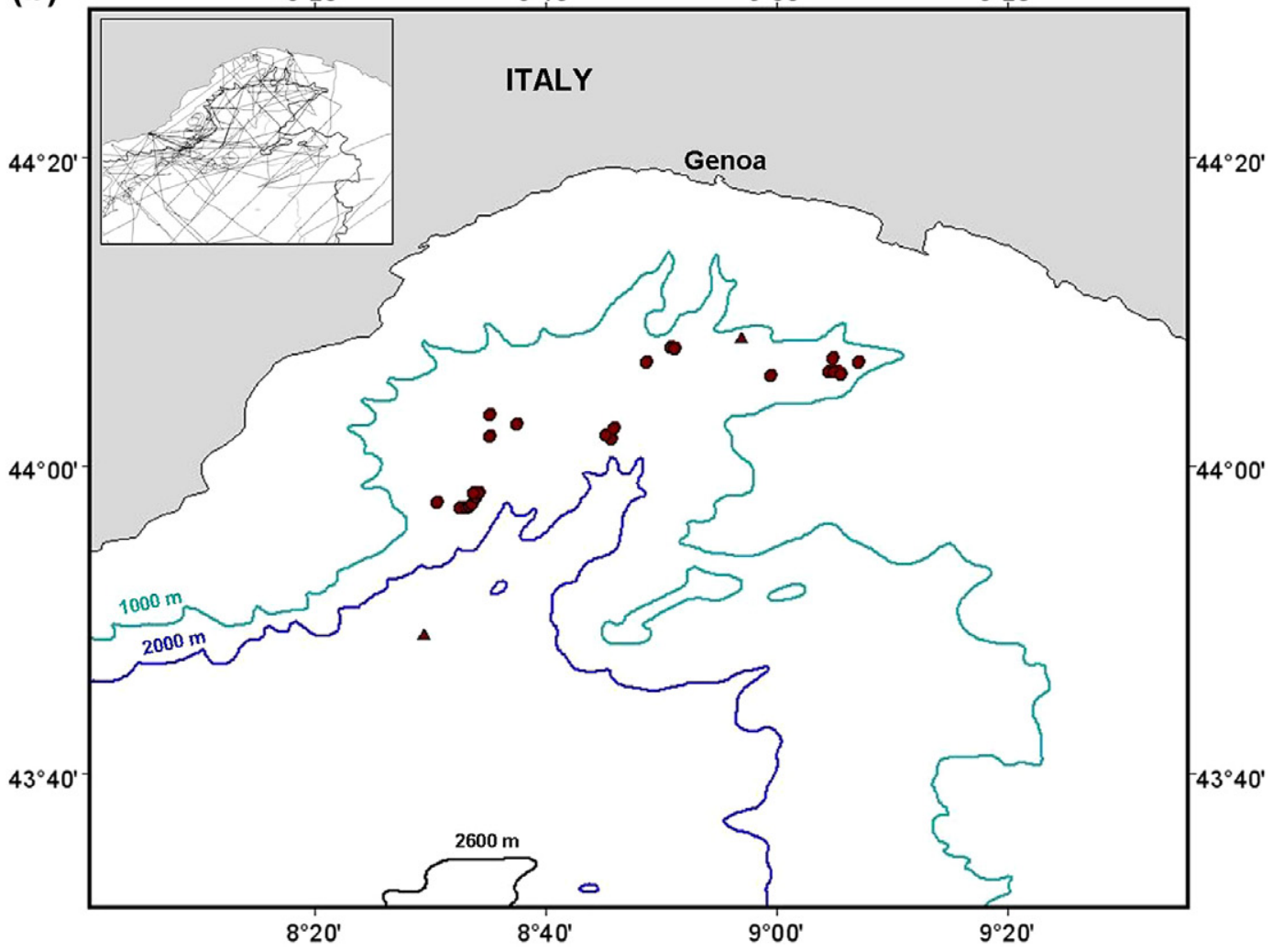

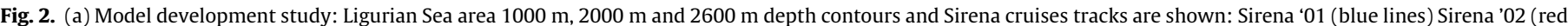

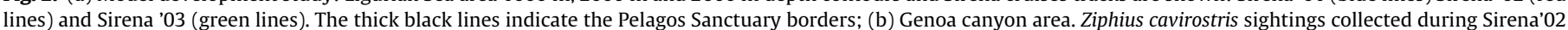

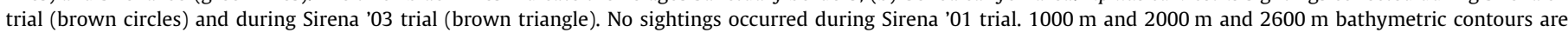

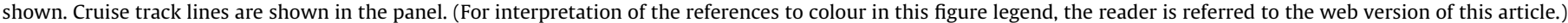




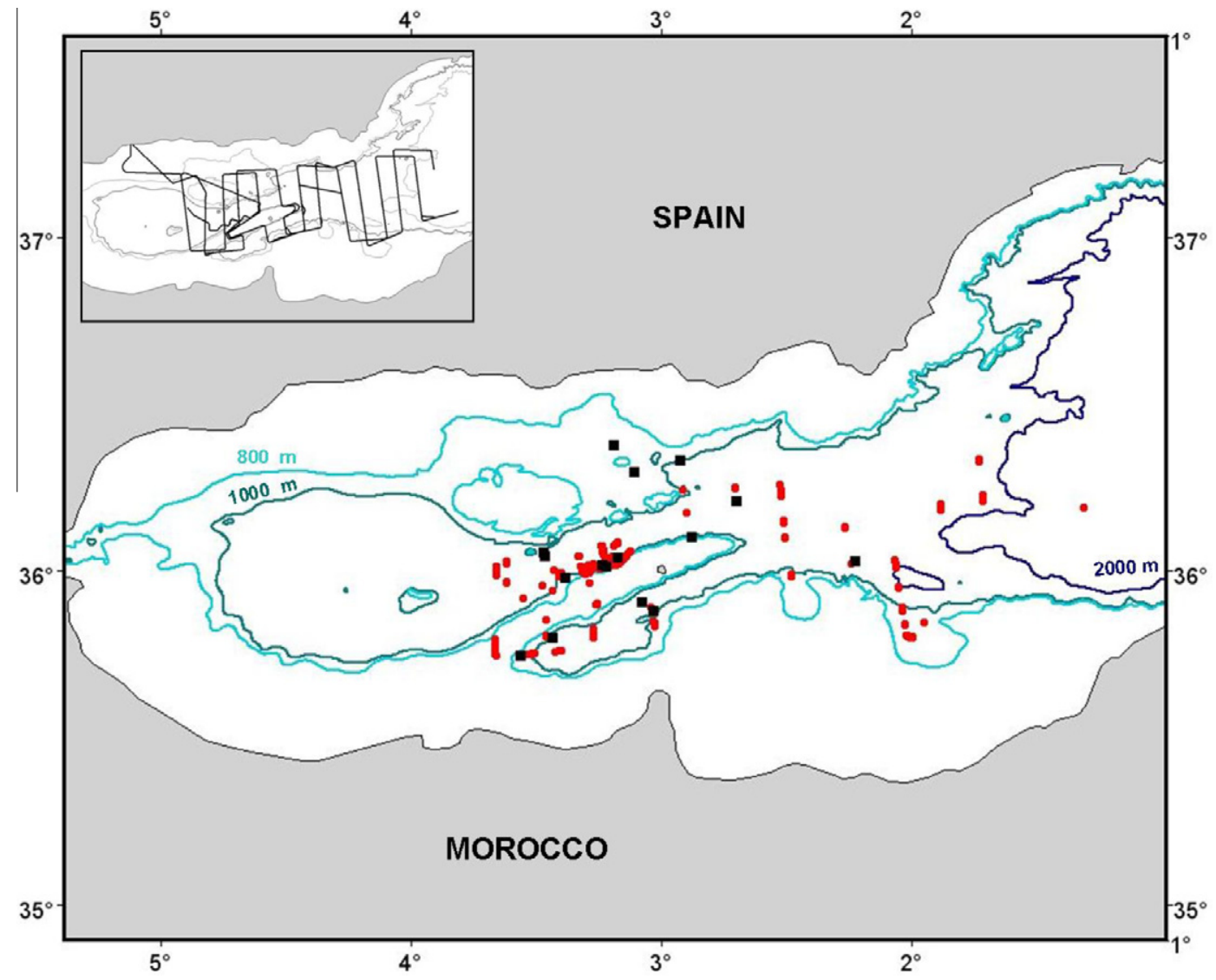

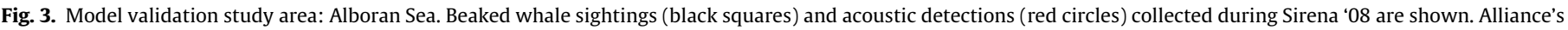
tracks are shown in the panel. (For interpretation of the references to colour in this figure legend, the reader is referred to the web version of this article.)

(SIRENA '03) in the Ligurian Sea region (see Fig. 2a). Survey details and statistics for this $50,000 \mathrm{~km}^{2}$ area are summarized in Table 1 . Visual sightings, passive acoustic detections and environmental data were collected by different research vessels, however, the main platform dedicated to the visual and passive acoustic marine mammal survey was the NATO Research Vessel (NRV) Alliance which was equipped with two big-eye vertical-scale binoculars (Fujinon, $25 * 150$, MTSX, field of view 2.75) mounted on the flying bridge on the forward port and starboard sides.

Cetacean observations were made while the ships were transiting at an average speed of 5-6 knots in sea state conditions corresponding to a Beaufort scale lower than 4 .

Cetacean sightings were collected during daylight hours from all the ships. On each research vessel, the visual team consisted of four expert observers rotated through three observation

\section{Table 1}

Summary of visual effort during the three SIRENA cruises conducted in the Ligurian Sea.

\begin{tabular}{llll}
\hline & Sirena '01 & Sirena ‘02 & Sirena '03 \\
\hline Time period & $\begin{array}{l}\text { 17 September-7 } \\
\text { October }\end{array}$ & 5-23 July & $\begin{array}{l}\text { 25 August-12 } \\
\text { September }\end{array}$ \\
\hline Research Vessels & NRV Alliance & NRV Alliance & NRV Alliance \\
& $\begin{array}{l}\text { ITS A. Magnaghi } \\
\text { T-boat Manning }\end{array}$ & & $\begin{array}{l}\text { ITS A. Magnaghi } \\
\text { CRV Leonardo }\end{array}$ \\
& RV Urania \\
Positive effort $(\mathrm{km})^{\mathrm{a}}$ & 2339.39 & 1700.54 & 3401.03 \\
$\begin{array}{l}\text { Zc sightings } \\
\text { Tot. sighting }\end{array}$ & 0 & 24 & 2 \\
\hline
\end{tabular}

${ }^{\text {a }}$ km surveyed with 4 visual observers on effort and Beaufort sea state lower than 4 . positions (port, center, and starboard) and the recording position. Observers with big-eye or regular binoculars (Fujinon $7 * 50$ FMT/ MT Field of view $7^{\circ} 30^{\prime}$ ) scanned the sea surface from $90^{\circ}$ port to $90^{\circ}$ starboard, where $0^{\circ}$ is on the track line. For every species encountered, time, bearing, radial distance, species, group size, behavior, sighting cue, and swimming orientation (aspect) data were recorded. Environmental data, including sea state, and effort status were recorded every 30 min or more frequently if changes in conditions occurred. All the visual sighting data were recorded through dedicated data logging software. A total of $7441 \mathrm{~km}$ $(4017 \mathrm{~nm})$ of track were surveyed under positive conditions (i.e. visual team on effort and Beaufort sea state lower than 4) and 545 encounters of cetacean species were collected on effort. Among these, 26 sightings of Cuvier's beaked whale were made. All beaked whale sightings occurred in the Genoa canyon region (in an area of about $10,600 \mathrm{~km}^{2}$ ) (Fig. 2b).

\subsubsection{Alboran Sea}

In the Alboran Sea the data were collected using the same methods and protocols employed in the Ligurian Sea area. The Alboran Sea trial was conducted during the time period of May 17June 18, 2008 onboard the NRV Alliance. Operations on the NRV Alliance were divided into two main phases. Between May19 and June 6, line transect surveys (according to Buckland et al. (1993)) were conducted using passive acoustic and visual methods to determine the presence and absence of cetaceans.

Transects covered more than $3300 \mathrm{~km}$. However, only $504 \mathrm{~km}$ were covered in positive conditions (i.e. visual team on effort with wind conditions lower than Beaufort scale 4). During the pre-defined transects, 316 on-effort cetacean encounters were made and among these, 16 were beaked whale sightings (i.e. 10 Cuvier's 
beaked whales, $Z$. cavirostris and 6 undetermined beaked whales). As for the Ligurian Sea area, all the data were recorded through dedicated data logging software.

Passive acoustic data were collected from the NRV Alliance using a small broadband array of hydrophones provided by CIBRA (Centro Interdisciplinare di Bioacustica e Ricerche Ambientali), University of Pavia, towed at depths up to $20 \mathrm{~m}$ at a speed of about 4.8 knots. The array ( $150 \mathrm{~m}$ tow cable, $12 \mathrm{~m}$ hose, $25 \mathrm{~m}$ tail, 2 channels output, $>70 \mathrm{kHz}$ bandwidth) was connected to a wideband low-noise front-end based on off-the-shelf components (Behringer VX2496 preamplifiers, Motu Traveler AD converter) to allow digital recording with nearly $90 \mathrm{kHz}$ bandwidth (192 kHz sampling rate). Continuous recording, real-time analysis and display were performed with the CIBRA SeaPro 2.0 software (Pavan et al., 2004, 2009).

Trained operators observed the real-time spectrographic display continuously 24-h per day. Acoustic detection events occurring in $1 \mathrm{~min}$ long time slots were logged and classified according to simple categories, one of which was matched to beaked whales' echolocation click features. Features used for classification were those visible on a high-resolution spectrogram (inter click interval, center frequency, bandwidth); these features were derived from literature (Johnson et al., 2004; Zimmer et al., 2005,2008 ) and other recordings (Pavan et al., 2009). Additional information such as the continuous variability of received click amplitude and the presence of a clear surface reflection with a delay indicating a deep source located within a detection cone below the sensors (Zimmer and Pavan, 2008; Pavan et al., unpublished results) were also used. Detections were saved along with navigation data to provide georeferenced data (i.e. to each detection was associated the ship position) minute by minute.

\subsubsection{Data preparation for the analysis}

The Ligurian Sea area was divided into 783 cells of $12 \times 10$ nautical miles $\left(0.2^{\circ}\right)$ grid size by means of GIS tools (i.e. ESRI ArcView version 3.2). Visual monitoring effort was evaluated in terms of kilometer of track line per cell unit. Only the data on-effort in favorable conditions (i.e. visual team on effort and wind conditions lower than 4 according to the Beaufort scale) were considered. $\mathrm{Cu}$ vier's beaked whale encounter rate was then calculated for each cell as the number of sightings per kilometer surveyed under favorable conditions. Depth data were obtained through the GEBCO One minute Digital Atlas and were gridded by means of the Spatial Analyst extention of the ESRI ArcView software. Slope was also calculated by using the Spatial Analyst tool according to Burrough (1986). In addition a time series of remotely sensed chlorophyll- $a$ data $\left(\mathrm{mg} \mathrm{m}^{-3}\right)$ was considered for the period 15-23 July 2002 using SeaWiFS 8 day data products, generated by the NASA Ocean Biology Processing Group (OBPG) through the Giovanni ${ }^{1}$ system (http://disc.sci.gsfc.nasa.gov/giovanni/). Through Giovanni, the SeaWiFS data products are binned and averaged to global $9 \times 9 \mathrm{~km}^{2}$ resolution on an equal-area grid. The system allows averaging of the mapped $0.083 \times 0.083^{\circ}$ grid values in any user-selected region. A time-series of 8 -days of chlorophyll-a average values was generated over the selected time period (four images extracted from June 26 to July 3, 2002). By means of a spatial interpolation, the chlorophyll-a mean, standard deviation (SD) minimum and maximum values $\left(\mathrm{mg} \mathrm{m}^{-3}\right)$ were calculated for every cell.

The chlorophyll- $a$ features were considered in the model together with physiographic features as covariates. Table 2 summarizes the covariates considered to model beaked whale presence/ absence.

\footnotetext{
${ }^{1}$ Giovanni is an acronym for the GES-DISC (Goddard Earth Sciences Data and Information Services Center) interactive online visualization and analysis infrastructure.
}

Table 2

Summary of the biological and physical characteristics considered for every cell employed as predictors for beaked whale presence/absence models.

Cell physical and biological characteristics

Mean depth (m)

Minimum depth (m)

Maximum depth (m)

Standard deviation depth $(\mathrm{m})$

Mean slope (\%)

Maximum slope (\%)

Standard deviation slope (\%)

Mean chlorophyll- $a\left(\mathrm{mg} \mathrm{m}^{-3}\right)$

Minimum chlorophyll- $a\left(\mathrm{mg} \mathrm{m}^{-3}\right)$

Maximum chlorophyll- $a\left(\mathrm{mg} \mathrm{m}^{-3}\right)$

Standard deviation chlorophyll- $a\left(\mathrm{mg} \mathrm{m}^{-3}\right)$

The Alboran Sea study area was divided into 247 cells of $12 \times 10$ nautical miles $\left(0.2^{\circ}\right)$. The effort was evaluated in terms of kilometers of track line per cell unit using the same methodology applied to the Ligurian Sea data set, including only the data with effort in favorable conditions. Moreover, as for Ligurian Sea, the bathymetric and chlorophyll- $a$ (acquired as generated by the Giovanni system for the period: May 17-June 18, 2008) information was spatially interpolated and gridded.

Passive acoustic beaked whale detections were recorded, and validated by re-analyzing the recordings considering the passive acoustic characteristics: continuous variability of received click amplitude and the presence of a clear surface reflection with a delay, as it was done in real time, but also examining waveforms and spectra in detail. Validated series of detections, occurring into 1 min time slots, were further aggregated into "clusters of detections", each cluster being a series of almost consecutive positive 1-min slots, separated from other clusters by more than $20 \mathrm{~min}$. In the following analysis, 59 clusters of detections were used, corresponding to a real distance of 1.6 miles (given the average speed of 4.8 knots). For the present work, only the presence/absence information inferred by 59 acoustic clusters was used.

\subsection{Statistical methods}

\subsubsection{Model development}

Binary logistic regression analysis (Afifi and Clark, 1996; Guisan and Zimmermann, 2000) was used to correlate the beaked whale presence/absence data to the physiographic and biological (i.e. chlorophyll-a) predictors. As the presence/absence data set was zero-inflated, to balance the number of absence observations, presence data were weighted on the basis of encounter rates, according to Azzellino et al. (2008). In order to select the best set of predictors, a forward stepwise method was used. Each predictor was tested for entry into the model one by one, based on the significance level of the score statistic. After each entry, variables that were already in the model were also tested for possible removal, based on the significance of the Wald statistic (Hosmer and Lemeshow, 2000). The variable with the largest probability greater than the specified threshold value was removed, and the model re-estimated; the procedure stopped when no more variables met the entry or removal criteria or when the current model was the same as the previous.

\subsubsection{Model validation}

Predictions for the Alboran Sea were made using the beaked whale habitat predictors used in the Ligurian Sea model. Model validation was then conducted using the beaked whale data collected in the Alboran Sea 2008 cruise and by examining the agreement between predictions and actual observations, using a $2 \times 2$ 
classification table (i.e. the confusion matrix according to Kohavi and Provost, 1998).

The confusion matrix can be used to calculate the indices describing predictive performance of models (Lindenmayer et al., 1990; Pearce et al., 1994): the sensitivity (i.e. the true positive fraction, the proportion of the positive observations in agreement with the presence predictions over the total positive observations) the specificity (i.e. the true negative fraction, the proportion of the negative observations in agreement with the absence predictions over the total negative observations), the false positive fraction and the false negative fraction (i.e. both measuring the proportion of case when the observations and the predictions disagree).

A further evaluation of the a priori model predictions was obtained by comparing the minimum distances from the sightings and the acoustic detections (i.e. the 59 clusters) and the cell centroids of high (i.e. predicted probability higher than 75\%) and low (i.e. predicted probability lower than $75 \%$ ) risk cells. Wilcoxon Signed Sum of Ranks test was used to test the distances.

\section{Results}

\subsection{Model development: a priori predictions based on the Ligurian Sea data set}

As the Sirena ' 02 cruise in the Ligurian Sea contained more than 90\% of Cuvier's beaked whale sightings and guaranteed the highest consistency of the data, this data set was selected for the modeling effort. The cell statistics of depth and slope (i.e. mean, minimum, maximum and standard deviation) were used as descriptors of the physical habitat within the regressions. Due to the weighting procedure used, the calibration set was made of 30 presence cells and 30 absence cells. The stepwise analysis stopped after 2 steps and selected at Step 1 the cell mean slope as the strongest predictor, and the standard deviation of the cell depths at Step 2 (see Table 3 ). The classification performances of the logistic models were evaluated in terms of confusion matrixes (Kohavi and

Table 3

A priori Ligurian Sea model: presence/absence of Cuvier's beaked whale were correlated with bathymetry features (i.e. mean slope, depth variability).

\begin{tabular}{llrllll}
\hline & & \multicolumn{1}{l}{ B } & S.E. & Wald & df & Sig. \\
\hline \multirow{2}{*}{ Step 1 } & Slope mean & 0.068 & 0.021 & 10.671 & 1 & 0.001 \\
& Constant & -3.592 & 1.299 & 7.64 & 1 & 0.006 \\
Step 2 & Depth std & -0.044 & 0.016 & 7.455 & 1 & 0.006 \\
& Slope mean & 0.292 & 0.104 & 7.916 & 1 & 0.005 \\
& Constant & -6.972 & 3.589 & 3.774 & 1 & 0.052
\end{tabular}

Note: the following statistics are shown: B: unstandardized regression coefficient; S.E.: Standard Error of B; Wald statistic for the included parameter; df: degrees of freedom; Sig.: level of significance.

Table 4

Confusion matrix of the model using bathymetric features as predictors (see Table 3).

\begin{tabular}{|c|c|c|c|c|c|}
\hline & \multirow[t]{2}{*}{ Observed } & & \multicolumn{2}{|c|}{$\begin{array}{l}\text { Predicted } \\
\text { Zc01 }\end{array}$} & \multirow{2}{*}{$\begin{array}{l}\text { Percentage } \\
\text { correct }\end{array}$} \\
\hline & & & Absence & Presence & \\
\hline \multirow[t]{3}{*}{ Step 1} & Zc01 & Absence & 18 & 12 & 59.3 \\
\hline & & Presence & 0 & 30 & 100 \\
\hline & Overall percentage & & & & 79.8 \\
\hline \multirow[t]{3}{*}{ Step 2} & Zc01 & Absence & 24 & 6 & 80.4 \\
\hline & & Presence & 2 & 28 & 94.0 \\
\hline & Overall percentage & & & & 87.2 \\
\hline
\end{tabular}

The cut value is .500 .
Provost, 1998). As shown in Table 4, the Step 1 model had a higher accuracy for predicting presence cells (100\%) whereas the accuracy was much lower for absence cells (59.3\%). On the other hand, the Step 2 model had a lower accuracy on presence (94\%) but a much higher accuracy on absence cells (80.4\%).

Moreover, the 15-23 July 2002 time series of chlorophyll-a data $\left(\mathrm{mg} \mathrm{m}^{-3}\right)$ was considered and the chlorophyll- $a$ cell statistics (i.e. mean, standard deviation, minimum and maximum values) were used as covariates in the regression analysis. The stepwise procedure selected at Step 1, the average of the cell minimum values as strongest predictor, and at Step 2, the average of the cell maximum values as second significant predictor (see Table 5 ). It should be observed that both the models with chlorophyll- $a$ show quite large standard errors, likely due to a certain degree of multicollinearity. The predictors and the intercept are in fact strongly correlated (see Table 6). Moreover, as it can be seen in Table 7, the classification performances of the model using chlorophyll- $a$ features as predictors are slightly lower than the previous model that uses bathymetric features. However, besides the differences in accuracy, it's interesting to observe that the two models show very similar predictions (Figs. 4 and 5) for the Ligurian Sea.

Table 5

A priori Ligurian Sea model: presence/absence of Cuvier's beaked whale were correlated with chlorophyll- $a$ features (i.e. the cell chlorophyll- $a$ minimum and maximum values).

\begin{tabular}{lllllll}
\hline & & B & S.E. & Wald & df & Sig. \\
\hline \multirow{2}{*}{ Step 1 } & Chlorophyll- $a$ min & -32.929 & 16.278 & 4.092 & 1 & 0.043 \\
& Constant & 3.825 & 1.857 & 4.242 & 1 & 0.039 \\
\multirow{2}{*}{ Step 2 } & Chlorophyll- $a$ max & 72963 & 22.756 & 10.281 & 1 & 0.001 \\
& Chlorophyll- $a$ min & -152.592 & 44.493 & 11.762 & 1 & 0.001 \\
& Constant & 6.362 & 2.229 & 8.149 & 1 & 0.004 \\
\hline
\end{tabular}

Note: the following statistics are shown: B: unstandardized regression coefficient; S.E.: Standard Error of B; Wald statistic for the included parameter; df: degrees of freedom; Sig.: level of significance.

Table 6

Correlation matrix between the chlorophyll- $a$ model parameters.

\begin{tabular}{llrll}
\hline & & \multicolumn{2}{c}{ Correlation matrix } \\
\cline { 3 - 5 } & & Constant & $\begin{array}{l}\text { Chlorophyll- } a \\
\text { min }\end{array}$ & $\begin{array}{l}\text { Chlorophyll- } a \\
\text { max }\end{array}$ \\
\hline \multirow{2}{*}{ Step 1 } & Constant & 1.000 & -0.989 & \\
& Chlorophyll- $a$ min & -0.989 & 1.000 & \\
Step 2 & Constant & 1.000 & -0.820 & 0.565 \\
& Chlorophyll- $a$ max & 0.565 & -0.933 & 1.000 \\
& Chlorophyll- $a$ min & -0.820 & 1.000 & -0.933 \\
\hline
\end{tabular}

Table 7

Confusion matrix of the model using chlorophyll- $a$ features as predictors (see Table 5).

\begin{tabular}{|c|c|c|c|c|c|}
\hline & \multirow[t]{2}{*}{ Observed } & & \multicolumn{2}{|l|}{$\begin{array}{l}\text { Predicted } \\
\text { Zc01 }\end{array}$} & \multirow{2}{*}{$\begin{array}{l}\text { Percentage } \\
\text { correct }\end{array}$} \\
\hline & & & Absence & Presence & \\
\hline \multirow[t]{3}{*}{ Step 1} & Zc01 & Absence & 12 & 18 & 40.7 \\
\hline & & Presence & 8 & 22 & 74.3 \\
\hline & Overall Percentage & & & & 57.6 \\
\hline \multirow[t]{3}{*}{ Step 2} & Zc01 & Absence & 22 & 8 & 72.4 \\
\hline & & Presence & 8 & 22 & 74.3 \\
\hline & Overall Percentage & & & & 73.3 \\
\hline
\end{tabular}

The cut value is .500 


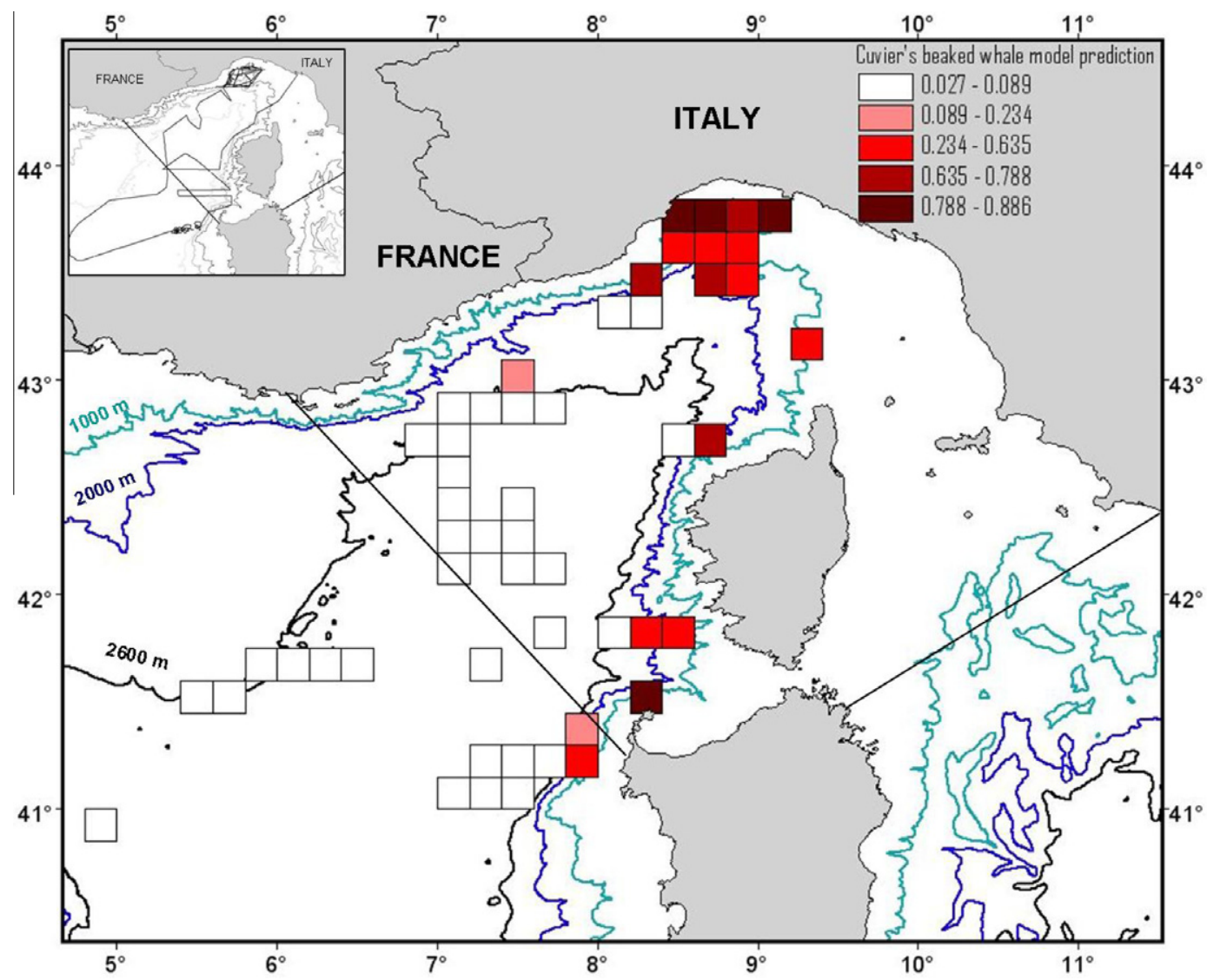

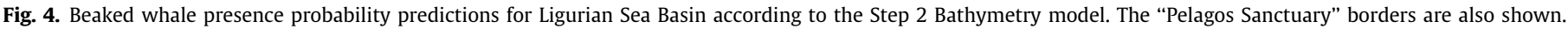
Sirena '02 track lines are shown in the panel.

\subsection{Model validation: evaluation of the a priori model prediction with the Alboran Sea data set}

By using the same predictors that were selected for the Ligurian Sea and applying the two a priori models to the Alboran Sea area, a map of presence and absence cells was generated. High risk cells were considered cells with presence probabilities higher than $75 \%$, whereas low risk cells were cells with a presence probability lower than $75 \%$. Such a prediction was than overlaid with the $\mathrm{Cu}-$ vier's beaked whale observations collected during the Sirena ' 08 cruise (see Fig. 6) and the accuracy of the models evaluated through analysis of cross-tabulation (see Tables 8).

It is interesting to observe that all the considered models showed exactly the same accuracy in terms of presence predictions whereas the accuracy for the absence predictions was found to be inversely correlated to the overall accuracy of the models as it was evaluated in the calibration phase. The highest accuracy for the absence cell predictions was the Step 2 chlorophyll- $a$ model, which had the lower overall accuracy for the calibration data set.

Moreover, to enlarge the validation data set in the Alboran Sea, the visual observations, which were strongly affected by unfavorable weather conditions for a large portion of the time at sea, were integrated with acoustic detections and cross-tabulated with the model predictions (see Table 9). It can be observed that the number of misclassifications for presence cells are always much higher than for the absence cells. The higher number of correct presence classifications was achieved through the Step 2 Bathymetry model, whereas the higher number of correct absence classifications was still obtained through the Chlorophyll- $a$ model.
Furthermore, to account for the mobility of the species, a different kind of analysis was also carried out considering the distances of each sighting or acoustic detection from the centroids of cells either low or high risk. The results are shown in Fig. 7. Wicoxon Signed Ranks test was applied, independently for visual sightings and acoustic detections, and resulted to be significant for both the models (see Table 10) showing that the cells predicted as high risk were significantly closer to visual sightings or acoustic detections than the cells predicted as low risk. It is interesting to point out that the mean distance of high risk cells from the visual sightings was of about 6-7 km. This should be kept in mind when drawing a priori risk prediction maps derived from models developed in different areas.

\subsection{Model development based on the Alboran Sea data}

Finally, to complete the evaluation of the a priori models, a new calibration was run using the Alboran Sea data set. Although with different coefficients, the stepwise regression analysis selected the same predictors of the a priori Ligurian Sea models (see Table 11) with almost the same accuracy (see Table 12). The chlorophyll- $a$ features, also selected as significant predictors by this new regression analysis, introduce multicollinearity in the models as it was observed for the Ligurian Sea data set. This effect may possibly be attributed to the chlorophyll- $a$ data resolution, since data were binned and averaged to a $9 \times 9 \mathrm{~km}^{2}$ grid that is approximately the same grid size of the analysis grid. The presence of spatial autocorrelation at such a resolution in the chlorophyll-a data set may be the reason of the multicollinearity observed when doing the regression analysis. 


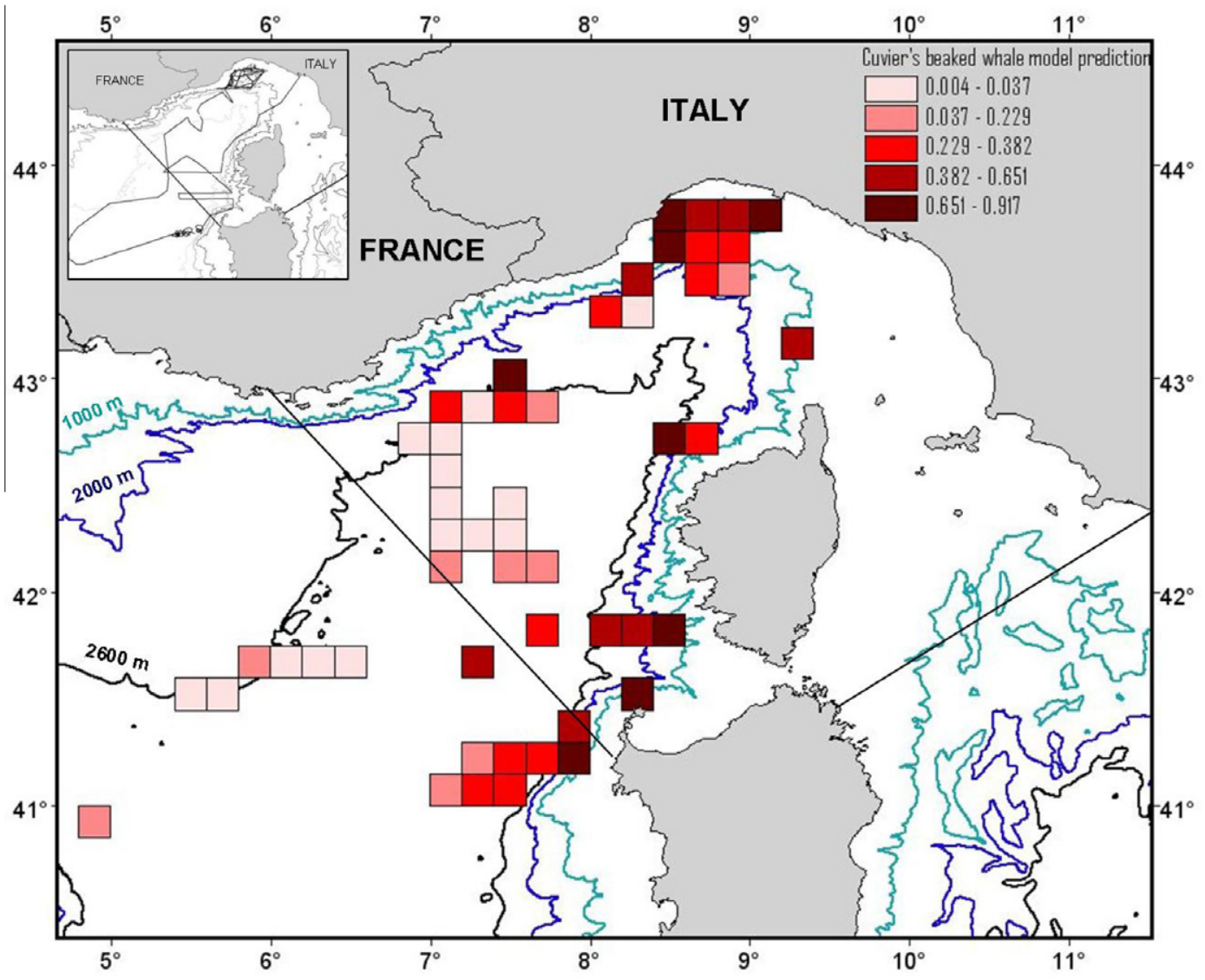

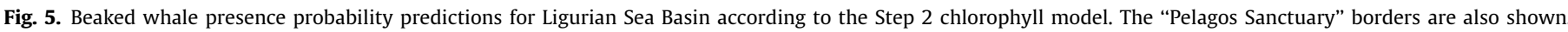
Sirena '02 track lines are shown in the panel.

\section{Discussion}

The avoidance of sensitive species' habitats (e.g. beaked whales proven sensitive to anthropogenic underwater sounds) is very often invoked as mitigation measure to minimize the impact for marine environments of the anthropogenic activities. Habitat avoidance implies the knowledge of the distribution of the potentially threatened species.

Although, the distribution of the majority of marine species is still largely unknown and poorly understood, Geographic Information System (GIS) technologies provide the opportunity for developing models of the species distributions that rely on existing information. The issue is to evaluate the reliability of these models and their applicability as knowledge-support tools for managing the risk to marine life caused by anthropogenic underwater sounds.

The quantification of species-environment relationships represents the core of predictive modeling in ecology. A variety of statistical models are currently in use (Guisan and Zimmermann, 2000) and these models are generally based on various hypotheses about the environmental factors that control the distribution of the species and communities. It is well known that the environmental variability may hamper the capability of static models to properly predict the species' response to changes. However, since only a few species have been studied in great detail in terms of their dynamic responses to environmental change, static distribution models very often remains the only usable approach (Woodward and Cramer, 1996). The process, which ends with the formulation of an ecological model, usually starts from an underlying ecological concept. In general, physical limits are caused by environmental and physiological constraints (e.g. direct and resource gradients). Using causal rather than non-causal factors or considering interspecies competition for fitting a static model may be discussed. From a mechanistic point of view, it would be desirable to predict the distribution of biotic entities on the basis of ecological parameters that are believed to be the causal, driving forces for their distribution and abundance. Such ecological factors are generally "inferred" from indirect predictors or proxies, since they are usually difficult or too expensive to be measured. Spatial uncertainties may also affect the predictions due to interpolation errors or the lack of the sufficient spatial coverage (MacLeod, 2010). On the other hand, directly derived topographic variables (slope, aspect, topographic position, or slope characteristics) are generated without much loss of precision and they could be used for a priori predictions needed when site-specific data are unavailable. Austin $(1980,1985)$, Austin et al. (1984), and Austin and Smith (1989) defined three types of ecological gradients, namely resource, direct, and indirect gradients. Resource gradients address matter and energy consumed by plants or animals (nutrients, water, light for plants, food and water for animals). Direct gradients are environmental parameters that have physiological importance, but are not consumed (temperature, $\mathrm{pH}$ ). Indirect gradients are variables that have no direct physiological relevance for a species' performance (slope, aspect, elevation, topographic position, habitat type, geology). They sometimes are more easily available and are often used because of their good correlation with observed species patterns. Indirect variables usually replace a combination of different resource and direct gradients in a simple way (Guisan et al., 1999). However, one drawback of using such indirect parameters is that a model can only be applied within a limited geographical extent 


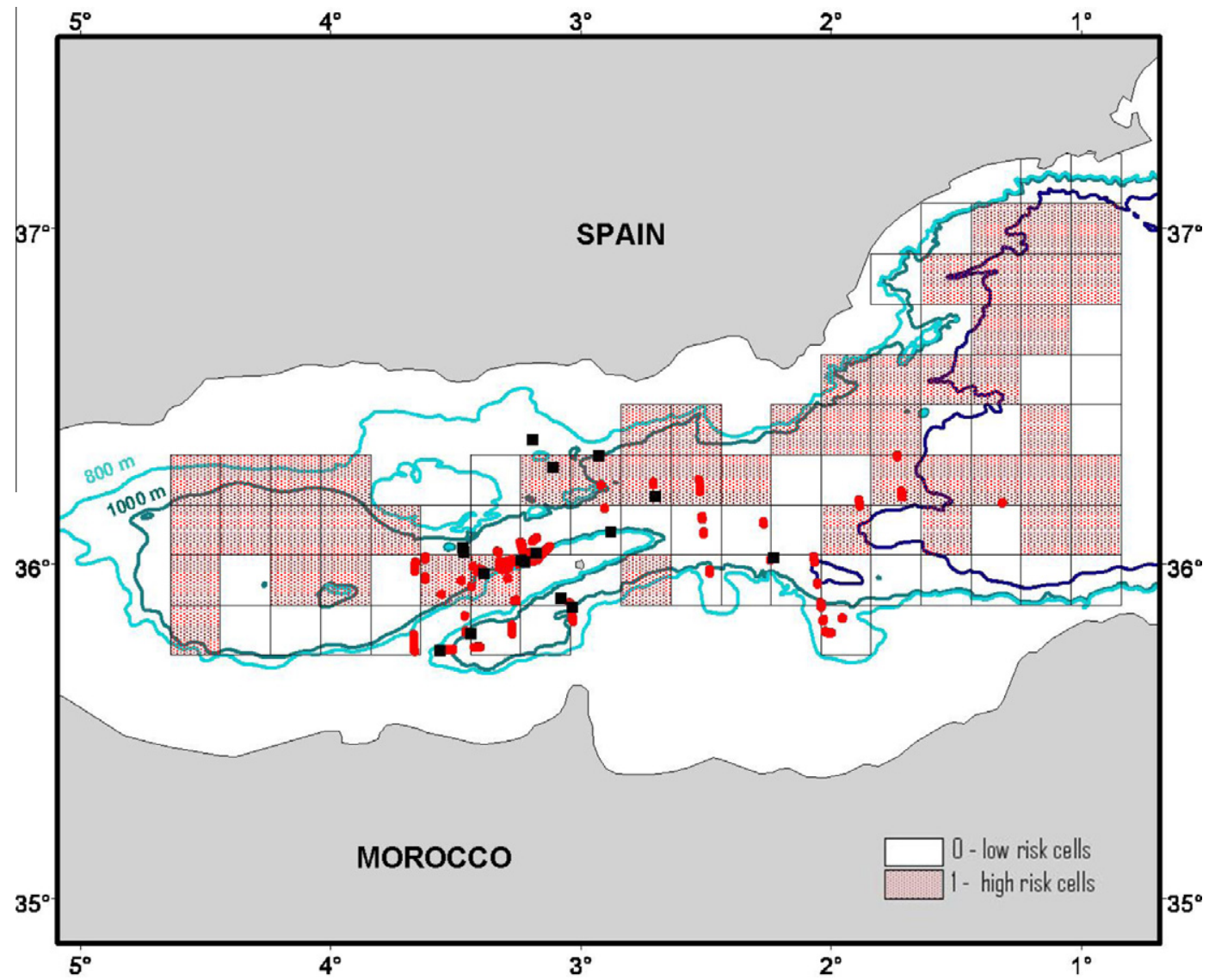

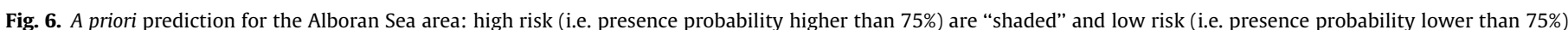

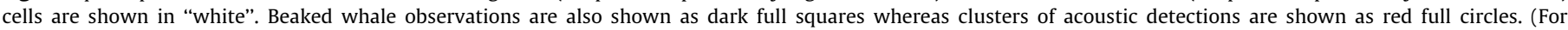
interpretation of the references to colour in this figure legend, the reader is referred to the web version of this article.)

Table 8

Cross-tabulation of the a priori model predictions versus the Cuvier's beaked whale observations. Three models are evaluated: Step 1 Bathymetry (i.e. Step 1 using bathymetric features as predictors). Step 2 Bathymetry (i.e. Step 2 using bathymetric features as predictors) and Step 2 chlorophyll- $a$ (i.e. Step 2 using chlorophyll- $a$ features as predictors).

\begin{tabular}{lllll}
\hline \multirow{2}{*}{ Predicted } & & \multicolumn{2}{l}{ Observed correct predictions } & $\begin{array}{l}\text { Overall } \\
\text { accuracy }\end{array}$ \\
\cline { 3 - 4 } & & Absence & Presence & \\
\hline & Step 1 Bathymetry & 34 & 5 & 39 \\
& Step 2 Bathymetry & 28 & 5 & 33 \\
& Step 2 chlorophyll- $a$ & 41 & 5 & 46 \\
& & Percent accuracy & \\
& Step 1 Bathymetry & $60.7 \%$ & $38.5 \%$ & $49.6 \%$ \\
Total & Step 2 Bathymetry & $50.0 \%$ & $38.5 \%$ & $44.2 \%$ \\
& Step 2 chlorophyll- $a$ & $73.2 \%$ & $38.5 \%$ & $55.8 \%$ \\
& & & & \\
\hline
\end{tabular}

without significant errors, because in a different region the same topographic position may reveal different combinations of direct and resource gradients. In turn, the use of direct and resource gradients as predictive parameters, in which case predictions are based on what is supposed to be more physiologically 'mechanistic', should ensure a model more general and applicable over larger areas. Model validation allows to verify whether "a model within its domain of applicability possesses a satisfactory range of accuracy that is consistent with the intended applications" (Schlesinger et al., 1979). A model may in fact be valid for one set of experimental conditions and invalid for another. A model is con- sidered valid for a set of experimental conditions if its accuracy is within its acceptable range, which is the amount of accuracy required for the model's intended purpose. This generally requires that the model's output variables, (e.g., in this case the presence probability of the species), be identified and their required amount of accuracy be specified. Moreover, two main approaches exist for evaluating the predictive power of a model. The first approach is to use a single data set to calibrate the model and then evaluate it by CV (Van Houwelingen and Le Cessie, 1990; Manel et al., 1999; Franklin et al. 2000), leave-one-out Jack-knife (JK, a special case of CV; Efron and Tibshirani, 1993; Manel et al., 1999) or bootstrap (Efron and Tibshirani, 1993; Guisan and Harrell, 2000) techniques. The second approach is to use two independent data sets, one for calibrating and another for evaluating the model (often called the training and evaluation data sets; e.g. Brzeziecki et al., 1993; Guisan et al., 1998, 1999; Zimmermann and Kienast, 1999). In this validation study we chose the second type of approach and investigated the reliability of a priori predictions, obtained by models developed for a different oceanographic region.

The questions we wanted to answer were the following: (1) is the accuracy of the a priori predictions, based on the models developed for the Ligurian Sea, adequate for the Alboran Sea area? and (2) is a uncertainty factor needed for the provided a priori predictions?

From the beginning of this study, we were absolutely aware of the relevant error rates associated with ecological models when they are transferred to areas different from their calibration sites (e.g. Pearce and Ferrier, 2000), however the rationale of this study was to test whether such a priori predictions could be useful when data are completely lacking as a sort of preliminary assessment of 
Table 9

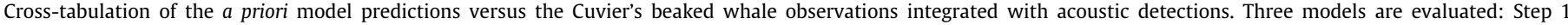

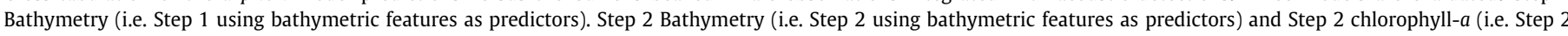
using chlorophyll- $a$ features as predictors). Percent correct predictions are highlighted in bold.

\begin{tabular}{|c|c|c|c|c|c|c|c|c|}
\hline & & & \multirow{2}{*}{$\begin{array}{l}\text { Absence of sightings } \\
\text { and acoustic detections }\end{array}$} & \multirow{2}{*}{$\begin{array}{l}\text { Acoustic } \\
\text { detection }\end{array}$} & \multirow{2}{*}{$\begin{array}{l}\text { Visual } \\
\text { sighting }\end{array}$} & \multirow{2}{*}{$\begin{array}{l}\text { Visual + acoustic } \\
\text { detection }\end{array}$} & \multicolumn{2}{|l|}{ Overall } \\
\hline & & & & & & & $\begin{array}{l}\text { Correct } \\
\text { classifications }\end{array}$ & $\begin{array}{l}\text { Missed } \\
\text { classifications }\end{array}$ \\
\hline \multirow[t]{4}{*}{ Step 1 Bathymetry } & Absence & Count & 21 & 13 & 2 & 6 & & \\
\hline & & $\%$ & $\mathbf{5 1 . 2 \%}$ & $86.7 \%$ & $66.7 \%$ & $60.0 \%$ & $51.2 \%$ & $48.8 \%$ \\
\hline & Presence & Count & 20 & 2 & 1 & 4 & & \\
\hline & & $\%$ & $48.8 \%$ & $13.3 \%$ & $33.3 \%$ & $40.0 \%$ & $25.0 \%$ & $75.0 \%$ \\
\hline \multirow[t]{4}{*}{ Step 2 Bathymetry } & Absence & Count & 18 & 10 & 2 & 6 & & \\
\hline & & $\%$ & $43.9 \%$ & $66.7 \%$ & $66.7 \%$ & $60.0 \%$ & $43.9 \%$ & $56.1 \%$ \\
\hline & Presence & Count & 23 & 5 & 1 & 4 & & \\
\hline & & $\%$ & $56.1 \%$ & $33.3 \%$ & $33.3 \%$ & $40.0 \%$ & $35.7 \%$ & $64.3 \%$ \\
\hline \multirow[t]{4}{*}{ Step 2 chlorophyll- $a$} & Absence & Count & 29 & 12 & 1 & 7 & & \\
\hline & & $\%$ & $70.7 \%$ & $80.0 \%$ & $33.3 \%$ & $70.0 \%$ & $70.7 \%$ & $29.3 \%$ \\
\hline & Presence & Count & 12 & 3 & 2 & 3 & & \\
\hline & & $\%$ & $29.3 \%$ & $20.0 \%$ & $66.7 \%$ & $30.0 \%$ & $28.6 \%$ & $71.4 \%$ \\
\hline Total & & Count & 41 & 15 & 3 & 10 & 69 & \\
\hline
\end{tabular}
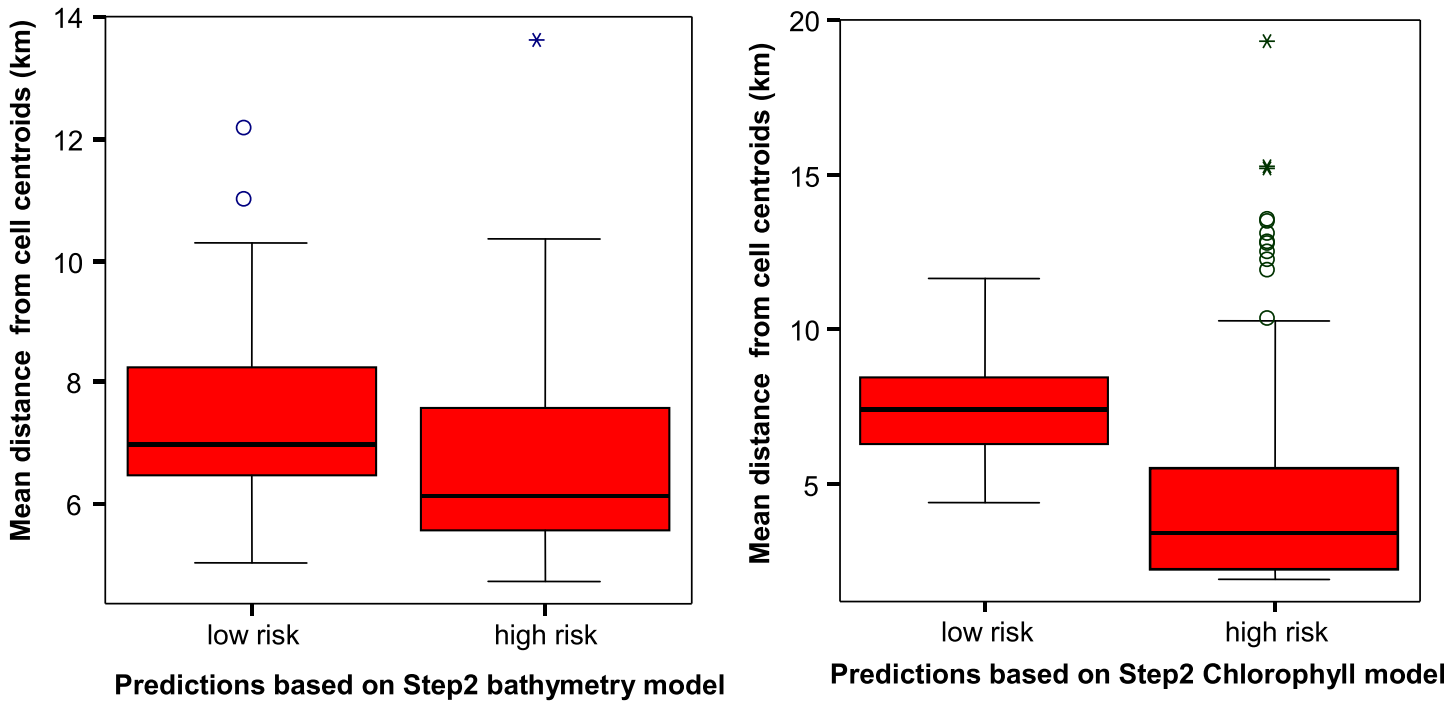

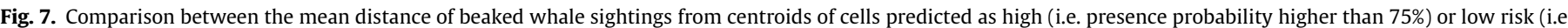

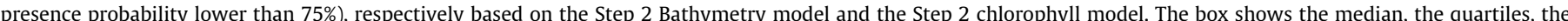
minimum and maximum values and the outliers. High risk cells are significantly closer to the sightings than low risk cells.

the area. Furthermore, beaked whales have been documented in literature (Baumgartner et al., 2001; Davis et al., 1998, 2002; Ferguson et al., 2006; Waring et al., 2001) as a species with a proved and solid relationship with the topographic features of the sea bottom. Several studies have, in fact, reported beaked whales as regularly observed over the continental slope in waters $200-2000 \mathrm{~m}$ depth, (Hamazaky, 2002; Hooker et al., 2002; MacLeod and Zuur, 2005; Waring et al., 2001) and near submarine canyons (Wimmer and Whitehead, 2004). In the Mediterranean Sea, Cuvier's beaked whale presence has been found associated with the continental slope area and submarine canyons (Azzellino et al., 2008; Cañadas et al.,2002; D'Amico et al., 2003; Gannier and Epinat, 2008; Moulins et al., 2007). This was another reason for trying a "validation" exercise using bathymetry as predictor for this species.

It is true that models cannot be tested as simply being true or false, but for providing good testable hypotheses, relevant to important management problems (i.e. the possibility of predicting a priori sensitive species habitats) (Levins, 1966). Therefore we defined our testable hypothesis as follows: "are the a priori predic- tions obtained by a model calibrated elsewhere significantly correlated with the observations?" The Wilcoxon test showed a significant correlation of these a priori predictions with the observations, although, as it was expected, the overall accuracy of such $a$ priori predictions was much lower than the accuracy estimated for the calibration area.

Our results also show that the high risk predictions (i.e. higher presence probability of the sensitive species) are generally no more than 7-8 km distant ${ }^{2}$ from the closest beaked whale sighting, suggesting that this distance may be applied as uncertainty factor to the a priori predictions. By incorporating this uncertainty factor, the a priori predictions may, in fact, become robust enough to support knowledge-based decisions for determining the ranking of priority areas that may be sensitive to anthropogenic impact within a region.

\footnotetext{
${ }^{2}$ Assuming the $75^{\circ}$ percentile of the distance distribution shown in 7 .
} 
Table 10

Wilcoxon Signed Ranks test results for the two a priori models versus. The mean cell distances from cell centroids are evaluated for visual sightings and acoustic detections for the cells predicted as high or low risk. All the significance levels refer to the Positive Ranks and values lower than 0.05 are outlined in Italic.

\begin{tabular}{|c|c|c|c|c|c|}
\hline Wilcoxon Signed Ranks & & $\mathrm{N}$ & Mean Rank & Sum of Ranks & Significance Level \\
\hline \multicolumn{6}{|c|}{ Step 2 Bathymetry model } \\
\hline \multirow[t]{4}{*}{ Visual Sightings } & Negative Ranks & 15 & 8.67 & 130 & \\
\hline & Positive Ranks & 1 & 6.00 & 6.00 & 0.00135 \\
\hline & Ties & 0 & & & \\
\hline & Total & 16 & & & \\
\hline \multirow[t]{4}{*}{ Acoustic detections } & Negative Ranks & 43 & 34.56 & 1486.00 & \\
\hline & Positive Ranks & 16 & 17.75 & 284.00 & 0.00001 \\
\hline & Ties & 0 & & & \\
\hline & Total & 59 & & & \\
\hline \multicolumn{6}{|c|}{ Step 2 Chlorophyll model } \\
\hline \multirow[t]{4}{*}{ Visual Sightings } & Negative Ranks & 14 & 8.71 & 122.00 & \\
\hline & Positive Ranks & 2 & 7.00 & 14.00 & 0.00523 \\
\hline & Ties & 0 & & & \\
\hline & Total & 16 & & & \\
\hline \multirow[t]{5}{*}{ Acoustic detections } & Negative Ranks & 43 & 34.56 & 1486.00 & \\
\hline & Positive Ranks & 16 & 17.75 & 284.00 & 0.067 (2-tailed) \\
\hline & & & & & 0.033 (1-tailed) \\
\hline & Ties & 0 & & & \\
\hline & Total & 59 & & & \\
\hline
\end{tabular}

Table 11

Alboran sea model: presence/absence of Cuvier's beaked whale were correlated with bathymetry and chlorophyll features.

\begin{tabular}{llccrrl}
\hline & & \multicolumn{1}{l}{ B } & SE & \multicolumn{1}{c}{ Wald } & df & Sig. \\
\hline Step 1 & Depth std & 0.006 & 0.001 & 17.831 & 1 & 0.000 \\
& Constant & -0.923 & 0.259 & 12.707 & 1 & 0.000 \\
Step 2 & Chlorophyll-a mean & 8.199 & 3.598 & 5.192 & 1 & 0.023 \\
& Depth std & 0.007 & 0.002 & 22.002 & 1 & 0.000 \\
& Constant & -3.580 & 1.208 & 8.788 & 1 & 0.003 \\
Step 3 & Chlorophyll mean & 14.67 & 4.375 & 11.246 & 1 & 0.001 \\
& Depth mean & 0.001 & 0.000 & 11.164 & 1 & 0.001 \\
& Depth std & 0.007 & 0.002 & 19.485 & 1 & 0.000 \\
& Constant & -6.453 & 1.592 & 16.429 & 1 & 0.000 \\
Step 4 & Chlorophyll mean & 10.9 & 4.379 & 6.197 & 1 & 0.013 \\
& Depth mean & 0.006 & 0.002 & 11.153 & 1 & 0.001 \\
& Depth std & -0.002 & 0.003 & 0.416 & 1 & 0.519 \\
& Depth min & -0.006 & 0.002 & 7.549 & 1 & 0.006 \\
& Constant & -5.32 & 1.582 & 11.31 & 1 & 0.001 \\
Step 5 & Chlorophyll mean & 12.096 & 4.035 & 8.984 & 1 & 0.003 \\
& Depth mean & 0.005 & 0.001 & 32.551 & 1 & 0.000 \\
& Depth min & -0.005 & 0.001 & 23.142 & 1 & 0.000 \\
& Constant & -5.732 & 1.471 & 15.184 & 1 & 0.000
\end{tabular}

Note: the following statistics are shown: B: unstandardized regression coefficient; SE: Standard Error of B; Wald statistic for the included parameter; df: degrees of freedom; Sig.: level of significance.

Fig. 8 shows the centroids of the high risk prediction cells to which a buffer of about $20 \mathrm{~km}$ (i.e. $12 \mathrm{~km}$ to account for the cell size and $8 \mathrm{~km}$ to account for the uncertainty factor) is applied. As the figure shows, very few sightings fall out of this buffer. This information may effectively contribute to identifying areas where exposure to anthropogenic noise should be mitigated following the precautionary principle. This criterion would provide a critical piece of information to be integrated with other elements (e.g. presence of SPAMI, high biodiversity areas, acoustic propagation conditions, etc.) for sensitive species. By using semi-empirical models of sound exposure, (e.g. models of the kind described in D'Spain et al., 2006), it may be possible to determine the seasonal acoustic propagation environment in these regions.

Regarding the a priori models, it is worthwhile to point out that their predictions, based on bathymetry and chlorophyll- $a$ features, respectively, were surprisingly quite comparable in both the study
Table 12

Confusion matrix of the models calibrated on the Alboran sea data set (see Table 11).

\begin{tabular}{|c|c|c|c|c|c|}
\hline & \multirow{2}{*}{\multicolumn{2}{|c|}{ Observed }} & \multicolumn{2}{|l|}{$\begin{array}{l}\text { Predicted } \\
\text { Zc01 } \\
\end{array}$} & \multirow[t]{2}{*}{ Percentage correct } \\
\hline & & & Absence & Presence & \\
\hline Step 1 & $\begin{array}{l}\text { Zc01 } \\
\text { Overa }\end{array}$ & $\begin{array}{c}\text { Absence } \\
\text { Presence } \\
\text { percentage }\end{array}$ & $\begin{array}{l}60 \\
40\end{array}$ & $\begin{array}{l}20 \\
36\end{array}$ & $\begin{array}{l}74.8 \\
47.3 \\
61.3\end{array}$ \\
\hline Step 2 & $\begin{array}{l}\text { Zc01 } \\
\text { Overa }\end{array}$ & $\begin{array}{c}\text { Absence } \\
\text { Presence } \\
\text { percentage }\end{array}$ & $\begin{array}{l}62 \\
18\end{array}$ & $\begin{array}{l}18 \\
58\end{array}$ & $\begin{array}{l}77.4 \\
76.7 \\
77\end{array}$ \\
\hline Step 3 & $\begin{array}{l}\text { Zc01 } \\
\text { Overa }\end{array}$ & $\begin{array}{c}\text { Absence } \\
\text { Presence } \\
\text { percentage }\end{array}$ & $\begin{array}{l}59 \\
18\end{array}$ & $\begin{array}{l}21 \\
58\end{array}$ & $\begin{array}{l}73.9 \\
76.7 \\
75.3\end{array}$ \\
\hline Step 4 & $\begin{array}{l}\text { Zc01 } \\
\text { Overa }\end{array}$ & $\begin{array}{c}\text { Absence } \\
\text { Presence } \\
\text { percentage }\end{array}$ & $\begin{array}{l}58 \\
18\end{array}$ & $\begin{array}{l}21 \\
58\end{array}$ & $\begin{array}{l}73.5 \\
76.2 \\
74.8\end{array}$ \\
\hline Step 5 & $\begin{array}{l}\text { Zc01 } \\
\text { Overa }\end{array}$ & $\begin{array}{c}\text { Absence } \\
\text { Presence } \\
\text { percentage }\end{array}$ & $\begin{array}{l}58 \\
18\end{array}$ & $\begin{array}{l}21 \\
58\end{array}$ & $\begin{array}{l}73.5 \\
76.2 \\
74.8\end{array}$ \\
\hline
\end{tabular}

Note: The cut value is .500 .

areas. The regression analysis applied to the Alboran Sea data set selected approximately the same predictors identified for the Ligurian Sea area and came up with models characterized by accuracies of the same magnitude observed for the Ligurian Sea data set. Since both bathymetry and chlorophyll- $a$ have been shown to be indirect predictors for beaked whales, it could be questioned how the observed patterns may be ecologically interpreted. Probably bathymetry and chlorophyll- $a$ are proxies of macro-scale features that indirectly delimit beaked whale habitats and may not apply for different species. However, as far as beaked whales are concerned, the macro-scale features involved are comparable between the study areas. These results are encouraging and support the hypothesis that modeling tools can be employed for the preliminary risk assessment of "unsurveyed" areas. The application of uncertainty buffers guarantees that the prediction process is appropriately conservative.

Based on a priori predictions of this kind, risk maps could be drawn and used as knowledge-based support for minimizing the potential impacts induced by human activities at sea. 


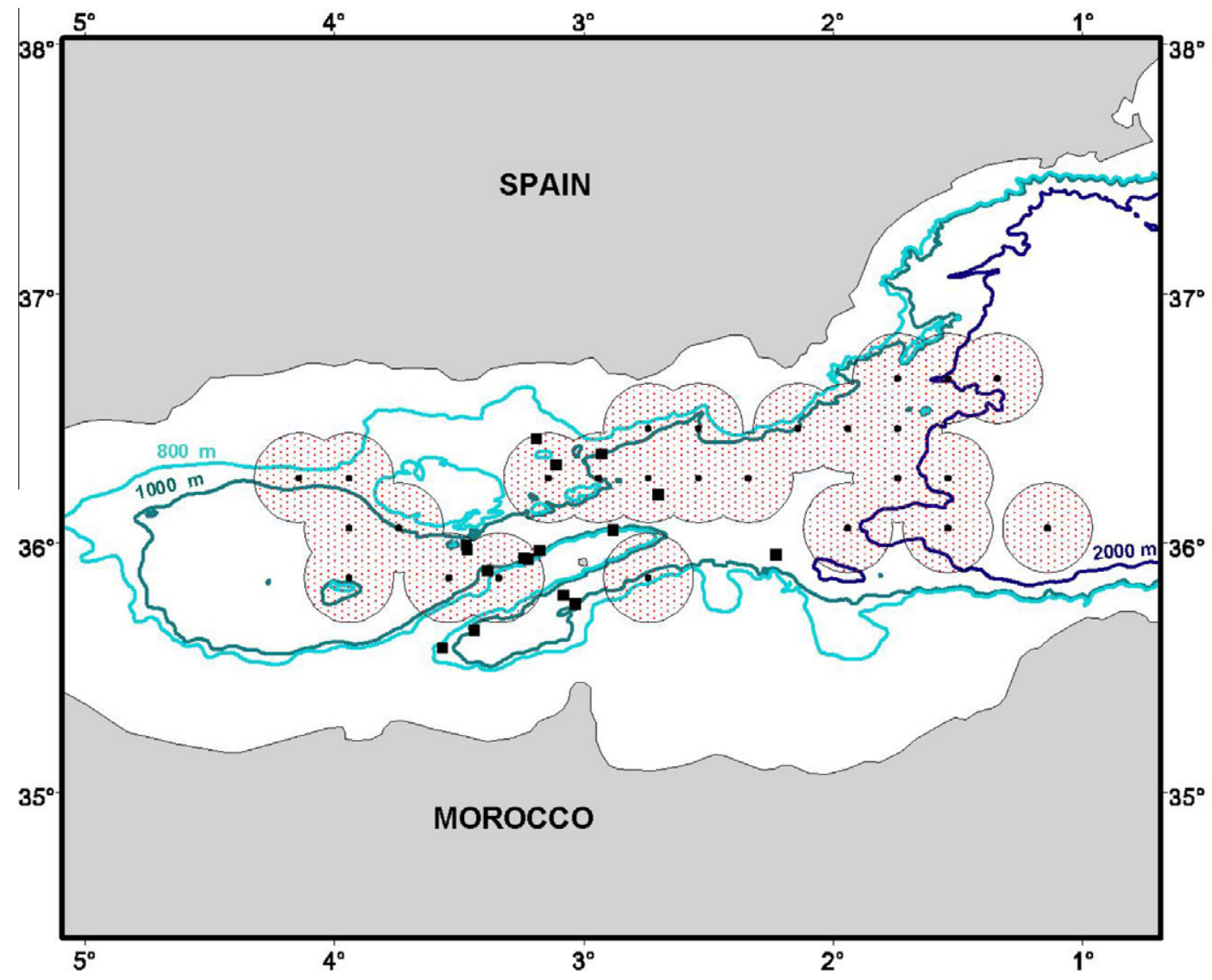

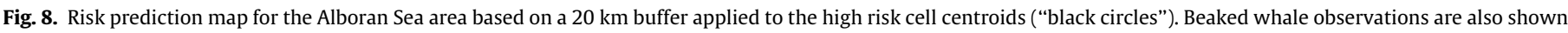
as dark full squares.

\section{Conclusions}

The inclusion of underwater noise with other human-induced pressures on the marine environment in the EU Marine Strategy Directive and the awareness that the occurrence and use of potentially harmful noise sources are likely to increase in the coming years, raise the question of how to mitigate potential harmful effects.

The ability to model the species presence may help in drawing knowledge-based mitigation actions that may lead to a conservative avoidance of areas predicted as high risk. Acoustic models may be used to evaluate the possible exposure to specific sound sources in these regions. Although many models that use different statistical approaches or were site specific have been used to predict the presence/absence of sensitive species, in very few occasions such models were evaluated for their transferability to areas different from their calibration sites. The aim of this study was to present a validation of the transferability of a habitat model developed in the Ligurian Sea area (NW Mediterranean Sea) to the Alboran Sea area (SW Mediterranean Sea). The accuracy of the $a$ priori predictions obtained from the Ligurian Sea models was found adequate for the Alboran Sea and lessons were also learned to determine a uncertainty factor that should be applied to the model predictions when used in areas different from the calibration site.

\section{Acknowledgements}

The authors would like to thank the anonymous reviewers that allowed to improve the paper. Thanks to N. Portunato, and M.
Quero for their assistance in assembling the Sirena trials beaked whale data base. The authors also acknowledge C. Francia for her involvement in the data preparation of the Sirena '08 data base of beaked whale acoustic detections. The authors also acknowledge and appreciate the support of the NRV Alliance, Captains and crew for their enthusiastic support of the Sirena trials. Additionally, the authors would like to acknowledge all NURC personnel who participated in the data-collection effort. In addition to all those mentioned above, the authors want also to thanks R. Gisiner for thoughtful discussions related to the complex topic of beaked whale and underwater anthropogenic sounds. This work was supported by the Office of Naval Research (Grant N00014-10-1-0533).

\section{References}

Afifi, A., Clark, V., 1996. Computer-Aided Multivariate Analysis. Texts in Statistica Science, fourth ed. Chapman \& Hall./CRC Press.

Aguilar de Soto, N., Johnson, M., Madsen, P.T., Tyack, P.L., Bocconcelli, A., Borsani, J.F. 2006. Does intense ship noise disrupt foraging in deep-diving Cuvier's beaked whales Ziphius cavirostris? Mar. Mamm. Sci. 22, 690-699.

Arnau, P., Liquete, C., Canals, M., 2004. River mouth plume events and their dispersal in the Northwestern Mediterranean Sea. Oceanography 17, 23-31.

Austin, M.P., 1980. Searching for a model for use in vegetation analysis. Vegetation 42, 11-21.

Austin, M.P., 1985. Continuum concept, ordination methods and niche theory. Annu. Rev. Ecol. Syst. 16, 39-61.

Austin, M.P., Smith, T.M., 1989. A new model for the continuum concept. Vegetation 83, 35-47.

Austin, M.P., Cunningham, R.B., Fleming, P.M., 1984. New approaches to direct gradient analysis using environmental scalars and statistical curve-fitting procedures. Vegetation 55, 11-27.

Azzellino, A., Airoldi, S., Gaspari, S., Nani, B., 2008. Habitat use of cetaceans along the Continental Slope and adjacent waters in the Western Ligurian Sea. Deep Sea Res. I 55, 296-323. 
Baird, R.W., Webster, D.L., McSweeney, D.J., Ligon, A.D., Schorr, G.S., Barlow, J., 2006. Diving behavior and ecology of Cuvier's (Ziphius cavirostris) and Blainville's (Mesoplodon densirostris) beaked whales in Hawaii. Can. J. Zool. 84, 1120-1128.

Baird, R.W., Webster, D.L., Schorr, G.S., McSweeney, D.J., Barlow, J., 2008. Die variation in beaked whale diving behavior. Mar. Mamm. Sci. 24 (3), 630-642.

Barlow, J., Gisiner, R., 2006. Mitigation monitoring and assessing the effect of anthropogenic sound on beaked whales. J. Cetacean Res. Manage. 7 (3), 239249.

Baumgartner, M.F., Mullin, K.D., May, L.N., Leming, T.D., 2001. Cetaceans habitats in the northern Gulf of Mexico. Fish. Bull. 99, 219-239.

Brzeziecki, B., Kienast, F., Wildi, O., 1993. A simulated map of the potential natural forest vegetation of Switzerland. J. Veg. Sci. 4, 499-508.

Buckland, S. T., Anderson, D. R., Burnham, K. P., and Laake, J. L., 1993. Distance sampling: Estimating abundance of biological populations. Chapman and Hall, London. Available from: http://www.ruwpa.st-and.ac.uk/distance

Burrough, P.A., 1986. Principles of Geographical Information Systems for Land Resources Assessment. Oxford University Press, New York.

Cañadas, A., Sagarminaga, R., 2000. The Alboran Sea, an important breeding and feeding ground for the long-finned pilot whale (Globicephala melas) in the Mediterranean Sea. Mar. Mamm. Sci. 16 (3), 513-529.

Cañadas, A., Sagarminaga, R., García-Tiscar, S., 2002. Cetacean distribution related with depth and slope in the Mediterranean waters off southern Spain. Deep Sea Res. I 11 (49), 2053-2073.

Cañadas, A., Sagarminaga, R., De Stephanis, R., Urquiola, E., Hammond, P., 2005 Habitat preference modelling as a conservation tool: proposals for marine protected areas for cetaceans in southern Spanish waters. Aquatic Conserv. Mar. Freshw. Ecosyst. 15, 495-521.

Cheney, R.E., Doblar, R.A., 1982. Structure and variability of the Alboran Sea frontal system. J. Geophys. Res. 87, 585-594.

Cox, T.M., Ragen, T.J., Read, A.J., Vos, E., Baird, R.W., Balcomb, K., et al., 2006. Understanding the impacts of anthropogenic sound on beaked whales. J. Cetacean Res. Manage. 7 (3), 177-187.

D’Amico, A., Bergamasco, A., Zanasca, P., Carniel, E., Portunato, N., Teloni, V., Mori, C., Barbanti, R., 2003. Qualitative correlation of marine mammals with physical and biological parameters in the Ligurian Sea. IEEE J. Ocean. Eng. 28 (1), 29-43.

D’Amico, A., Gisiner, R.C., Ketten, D.R., Hammock, J.A., Johnson, C., Tyack, P.L., Mead, J., 2009. Beaked whale strandings and naval exercises. Aquatic Mammals 35 (4), $452-472$.

Davis, R.W., Fargion, G.S., May, N., Leming, T.D., Baumgartner, M.F., Evans, W.E., Hansen, L.J., Mullin, K., 1998. Physical habitat of cetaceans along the continental slope in the north-central and western Gulf of Mexico. Mar. Mamm. Sci. 14 (3) 490-507.

Davis, R.W., Ortega-Ortiz, J.G., Ribic, C.A., Evans, W.E., Biggs, D.C., Ressler, P.H., Cady, R.B., Leben, R.R., Mullin, K.D., Wursig, B., 2002. Cetacean habitat in the northern oceanic Gulf of Mexico. Deep Sea Res. I 49, 121-142.

DFO, 2004. Review of Scientific Information on Impacts of Seismic Sound on Fish, Invertebrates, Marine Turtles and Marine Mammals. DFO Can. Sci. Advis. Sec. Habitat Status Report, 2004/002.

Directive 2008/56/EC of the European Parliament and of the Council of 17 June 2008 establishing a framework for community action in the field of marine environmental policy (Marine Strategy Framework Directive).

Dolman, S., Evans, P.G.H., Notarbartolo di Sciara, G., Frisch, H., 2011. Active sonar beaked whales and European regional policy. Mar. Pollut. Bull. 63 (1-4), 27-34

D'Spain, G.L., D'Amico, A., Fromm, D. 2006. Properties of the underwater sound fields during some well documented beaked whale mass stranding events. J. Cetacean Res. Manage. 7 (3), 223-228.

Efron, B., Tibshirani, R., 1993. An Introduction to the Bootstrap. Chapman and Hall, New York.

Castellote, M., Esteban, J.A., Clark, C.W., Raga, J.A., 2008. A new Mediterranean fin whale (Balaenoptera physalus) dispersion path and winter ground. 22nd Annual Conference of the European Cetacean Society. Egmond aan Zee, The Netherlands, 10-12 March 2008.

Evans, P.G.H., Miller, L.A., 2004. Proceedings of the Workshop on Active Sonar and Cetaceans, Las Palmas, Gran Canaria, 8 March 2003. ECS Newsletter 42,78.

Ferguson, M.C., Barlow, J., Reilly, S.B., Gerrodette, T., 2006. Predicting Cuvier's (Ziphius cavirostris) and Mesopolodon beaked whale population density from habitat characteristics in the eastern tropical Pacific Ocean. J. Cetacean Res. Manage. 7 (3), 287-299.

Fernández, A., Edwards, J.F., Rodríguea, F., Espinosa de los Monteros, A., Herráez, P. Castro, P., Jaber, J.R., Martin, V., Arbelo, M., 2005. "Gas and fat embolic syndrome" involving a mass stranding of Beaked whales (family Ziphiidae) exposed to anthropogenic sonar signals. Vet. Pathol. 42, 446-457.

Forcada, J., Notarbartolo Di Sciara, G., Fabbri, F., 1995. Abundance of fin whales and striped dolphins summering in the Corso-Ligurian Basin. Mammalia 59, 127 140.

Forcada, J., Aguilar, A., Hammond, P., Pastor, X., Aguilar, R., 1996. Distribution and abundance of fin whales (Balaenoptera physalus) in the western Mediterranean during the summer. J. Zool. 238, 23-34.

Franklin, J., McCullough, P., Gray, C., 2000. Terrain variables used for predictive mapping of vegetation communities in Southern California. In: Wilson, J.P. Gallant, J.C. (Eds.), Terrain Analysis: Principles and Applications. Wiley, New York

Frantzis, A., 1998. Does acoustic testing strand whales? Nature 392, 29

Frantzis, A., Goold, J.C., Sharsoulis, E.K., Taroudakis, M.I., Kandia, V., 2002. Clicks from Cuvier's beaked whales, Ziphius cavirostris. J. Acoust. Soc. Am. 112, 34-37.
Freitas, L., 2004. The stranding of three Cuvier's beaked whales Ziphius cavirostris in Madeira Archipelago May 2000. In: Evans, P., Miller, L. (Eds.), Proceedings of the Workshop on Active Sonar and Cetaceans held at the European Cetacean Society held at the 17th Annual Conference Las Palmas, Gran Canaria, 8 March 2003, ECS Newsletter 42, pp. 28-34.

Gannier, A., Epinat, J., 2008. Cuvier's beaked whale distribution in the Mediterranean Sea: results from small boat surveys 1996-2007. J. Mar. Biol. Assoc. UK 88 (6), 1245-1251.

Gonnella, J., Lamy, A., Millot, C., 1977. Upwellings d'été sur la cote méditerranéenne francaise. Annales Hydographiques. 5, 87-94.

Gordon, J.C.D., Matthews, J.N., Panigada, S., Gannier, A., Borsani, J.F., Notarbartolo di Sciara, G., 2000. Distribution and relative abundance of striped dolphins, and distribution of sperm whales in the Ligurian Sea cetacean sanctuary: results from a collaboration using acoustic monitoring techniques. J. Cetacean Res. Manage. 2 (1), 27-36.

Guisan, A., Harrell, F.E., 2000. Ordinal response regression models in ecology. J. Veg. Sci. 11, 617-626.

Guisan, A., Zimmermann, N.E., 2000. Predictive habitat distribution models in ecology. Ecol. Model. 135, 147-186.

Guisan, A., Theurillat, J.-P., Kienast, F., 1998. Predicting the potential distribution of plant species in an alpine environment. J. Veg. Sci. 9, 65-74.

Guisan, A., Weiss, S.B., Weiss, A.D., 1999. GLM versus CCA spatial modeling of plant species distribution. Plant Ecol. 143, 107-122.

Hamazaky, T., 2002. Spatiotemporal prediction models of North Atlantic Ocean (from Cape Hatteras, North Carolina, U.S.A. to nova Scotia, Canada) cetacean habitats in the mid-western. Mar. Mamm. Sci. 18 (4), 920-939.

Harwood, J., 2000. Risk assessment and decision analysis in conservation. Biol. Conserv. 95, 219-226

Heyning, J.E., 1989. Cuvier's beaked whale, Ziphius cavirostris G. Cuvier, 1823. In: Ridgway, S.H., Harrison, R. (Eds.), Handbook of Marine Mammals, 4. Academic Press, London, pp. 289-307.

Hobson, R.P., Martin, A.R., 1996. Behaviour and dive times of Arnoux's beaked whales, Berardius arnuxii at narrow leads in fast ice. Can. J. Zool. 74, 388393.

Hooker, S.K., Baird, R.W., 1999. Deep-diving behaviour of the northern bottlenose whale, Hyperoodon ampullatus (Cetacea: Ziphiidae). Proc. R. Soc. Lond. B Biol. Sci. 266, 671-676.

Hooker, S.K., Whitehead, H., Gowans, S., Baird, R.W., 2002. Fluctuations in distribution and patterns of individual range use of northern bottlenose whales. Mar. Ecol. Prog. Ser. 225, 287-297.

Hosmer, D.W., Lemeshow, S., 2000. Applied Logistic Regression, second ed. John Wiley \& Sons, New York.

Johnson, M.P., Tyack, P.L., 2003. A digital acoustic recording tag for measuring the response of wild marine mammals to sound. IEEE J. Ocean. Eng. 28, 3-12.

Johnson, M., Madsen, P.T., Zimmer, W.M.X., Aguilar de Soto, N., Tyack, P.L., 2004. Beaked whales echolocate on prey. Proc. R. Soc. London, Ser. B 271, S383-S386.

Johnson, M., Madsen, P.T., Zimmer, W.M.X., Aguilar de Soto, N., Tyack, P.L., 2006. Foraging Blainville's beaked whales (Mesoplodon densirostris) produce distinct click types matched to different phases of echolocation. J. Exp. Biol. 209, 50385050.

Johnson, M., Hickmott, L.S., Aguilar Soto, N., Madsen, P.T., 2007. Echolocation behaviour adapted to prey in foraging Blainville's beaked whale (Mesoplodon densirostris) Proc. Biol. Sci. B 275, 133-139.

Joint Nature Conservation Commitee (JNCC), 2004. Guidelines for minimising acoustic disturbance to marine mammals form seismic surveys.

Jones, B.A., Stanton, T.K., Lavery, A.C., Johnson, M.P., 2008. Classification of broadband echoes from prey of a foraging Blainville's beaked whale. J. Acoust. Soc. Am. 123 (3), 1753-1762.

Klima, E.F., Gitschlag, G.R., Renaud, M.L., 1988. Impacts of the explosive removal of offshore petroleum platforms on sea turtles and dolphins. Mar. Fish. Rev. 50 (3), 33-42.

Kohavi, R., Provost, F., 1998. Machine Learning 30, 271-274.

Levins, R., 1966. The strategy of model building in population ecology. Am. Sci. 54, 421-431.

Lindenmayer, D.B., Cunningham, R.B., Tanton, M.T., Smith, A.P., Nix, H.A., 1990. Habitat requirements of the mountain brushtail possum and the greater glider in the montane ash-type forests of the central highlands of Victoria. Aust. Wildl. Res. 17, 467-478.

MacLeod, C.D., 2000. Distribution of beaked whales of the genus Mesoplodon in the North Atlantic (Order: Cetacea, Family: Ziphiidae). Mammal Rev. 30, 1-8.

MacLeod, C. D., 2010. Habitat representativeness score (HRS): a novel concept for objectively assessing the suitability of survey coverage for modelling the distribution of marine species. J. Mar. Biol. Assoc. UK. doi:10.1017/ s0025315410000408.

MacLeod, C.D., D'Amico, A., 2006. A review of knowledge about behavior and ecology of beaked whales in relation to assessing and mitigating potential impacts from anthropogenic noise. J. Cetacean Res. Manage. 7 (3), 211-221.

MacLeod, C.D., Mitchell, G., 2006. Known key areas for beaked whales around the world. J. Cetacean Res. Manage. 7 (3), 309-322.

MacLeod, C.D., Zuur, A.F., 2005. Habitat utilisation by Blainville's beaked whales off Great Abaco, Northern Bahamas, in relation to seabed topography. Mar. Biol. $174,1-11$

Madsen, P.T., Johnson, M., Aguilar de Soto, N., Zimmer, W.M.X., Tyack, P.L., 2005. Biosonar performance of foraging beaked whales Mesoplodon densirostris. J. Exp. Biol. 208, 181-194. 
Madsen, P.T., Wilson, M., Johnson, M., Hanlon, R.T., Bocconcelli, A., Aguilar de Soto, N., Tyack, P.L., 2007. Clicking for calamari: toothed whales can echolocate squid Loligo pealeii. Aquat. Biol. 1, 141-150.

Manel, S., Dias, J.-M., Ormerod, S.J., 1999. Comparing discriminant analysis, neural networks and logistic regression for predicting species distributions: a case study with a Himalayan river bird. Ecol. Model. 120, 337-347.

Martín, V., Servidio, A., \& García, S., 2004. Mass strandings of beaked whales in the Canary Islands, In: Evans, P., Miller, L. (Eds.), Proceedings of the Workshop on Active Sonar and Cetaceans held at the European Cetacean Society held at the 17th Annual Conference Las Palmas, Gran Canaria, 8 March 2003. ECS Newsletter 42, pp. 33-36.

Martín Martel, V., 2002. Especial varamiento de cetáceos-Viceconsejería de Medio Ambiente. Gran Canaria: Government of the Canary Islands. Available from: http://www.gobcan.es/medioambiente/varamientos.

McCauley, R.D., Duncan, A.J., Fewtrell, J., Jenner, C., Jenner, M.-N., Penrose, J.D., Prince, R.I.T., Adhitya, A., Murdoch, J., McCabe, K., 1999. Marine Mammal Seismic Surveys: Analysis and Propagation of Air-Gun Signals and Effects of AirGun Exposure on Humpback Whales, Sea Turtles Fishes and Squid. Curtin University, Centre for Marine Science and Technology.

McCauley, R.D., Fewtrell, J., Duncan, A.J., Jenner, C., Jenner, M.-N., Penrose, J.D., Prince, R.I.T., Adhitya, A., Murdoch, J. \& McCabe, K., 2000. Marine seismic surveys: Analysis and propagation of air gun signals and effects of airgun exposure on Humpback whales, sea turtles, fishes and squid. Project CMST 163, Report pp. 99-15.

Millot, C., 1999. Circulation in the Western Mediterranean Sea. J. Marine Syst. 20, 432-442.

Misic, C., Fabiano, M., 2006. Coenzymatic activity and its relationship to chlorophyll- $a$ and bacteria in the Gulf of Genoa (Ligurian Sea, NM Mediterranean). J. Marine Syst. 60, 193-206.

Moulins, A., Rosso, M., Nani, B., Wurtz, M., 2007. Aspects of the distribution of Cuvier's beaked whale (Ziphius cavirostris) in relation to topographic features in the Pelagos Sanctuary (north-western Mediterranean Sea). J. Mar. Biol. Assoc. UK 87, 177-186.

Notarbartolo di Sciara, G., 2008. The Pelagos Sanctuary for Mediterranean marine mammals. Aquatic Conserv. Mar. Freshw. Ecosyst. 18, 367-391.

NURC-SP-2008-003, Special Publication, 2006. Human Diver and Marine Mammal Risk Mitigation Rules and Procedures(second Edition). Available from: http:// www.nurc.nato.int/publications/pubs/2008/NURC-SP-2008-003.

Papanicolopulu, I., 2011. Warships and noise regulation: the international legal framework. Mar. Pollut. Bull. 63 (1-4), 35-39.

Parsons, E.C.M., Dolman, S.J., Wright, A.J., Rose, N.A., Burns, W.C.G., 2008. Navy sonar and cetaceans: just how much does the gun need to smoke before we act? Mar. Pollut. Bull. 56, 1248-1257.

Pavan, G., 2006. Guidelines to address the issue of the impact of anthropogenic noise on marine mammals in the ACCOBAMS area. Report prepared for the 4th meeting of the ACCOBAMS Scientific Committee, Monaco.

Pavan, G., Fossati, C., Manghi, M., Priano, M., 2004. Passive acoustics tools for the implementation of Acoustic Risk Mitigation Policies. In: Evans, P. G. H., Miller, L. A. (Eds.), "Proceedings of the Workshop on Active Sonar and Cetaceans", 17th ECS Conference, March 2003,European Cetacean Society Newsletter No. 42 Special Issue, pp. 52-58.

Pavan, G., Fossati, C., Priano, M., Manghi, M., 2009. Acoustic detection of Cuvier's beaked whales (Ziphius cavirostris). In: Dolman,S., MacLeod,C., Evans,P. G. H. (Eds.), Proceedings of the Workshop "Beaked Whale Research". ECS Special Publication Series no. 51. 21st Annual Meeting of the European Cetacean Society, San Sebastian, Spain, 26th April 2007, pp. 31-35.

Pearce, J., Ferrier, S., 2000. Evaluating the predictive performance of habitat models developed using logistic regression. Ecol. Model. 133 (3), 225-245.
Pearce, J.L., Burgman, M.A., Franklin, D.C., 1994. Habitat selection by helmeted honeyeaters. Wildl. Res. 21, 53-63.

Podestá, M., D’Amico, A., Pavan, G., Drouga, A., Komnenou, A., Portunato, N., 2006. A review of Ziphius cavirostris strandings in the Mediterranean Sea. J. Cetacean Res. Manage. 7 (3), 251-326.

Popper, A.N., Fewtrell, J., Smith, M.E., McCauley, R.D., 2004. Anthropogenic sound: effects on the behaviour and physiology of fishes. J. Mar. Technol. Soc. 37 (4), 35-40.

Popper, A.N., Smith, M.E., Cott, P.A., Hanna, B.W., MacGillivray, A.O., Austin, M.E., Mann, D.A., 2005. Effects of exposure to seismic airgun use on hearing of three fish species. J. Acoust. Soc. Am. 11, 3958-3971.

Popper, A.N., Halvorsen, M.B., Kane, E., Miller, D.D., Smith, M.E., Stein, P., Wysocki, L.E., 2007. The effects of high-intensity, low-frequency active sonar on rainbow trout. J. Acoust. Soc. Am. 122, 623-635.

Rohling, E.J., Den Dulk, M., Pujol, C., Vergnaud Grazzini, C., 1995. Abrupt hydrographic change in the Alborn Sea (Western Mediterranean) abound 8000 Y BP. Deep Sea Res. I 42 (9), 1609-1919.

Schlesinger, S., Crosbie, R.E., Gagne, R., Innis, G.S., Lalwani, C.S., Loch, J., Sylvester, J., Wright, R.D., Kheir, N., Bartos, D., 1979. Terminology for model credibility. Simulation 32 (3), 103-104.

Simmonds, M.P., Lopez-Jurado, L.F., 1991. Whales and the military. Nature 351, 448

Southall, B.L., Bowles, A.E., Ellison, W.T., Finneran, J.J., Gentry, R.L., Greene Jr., C.R. Kastak, D., Ketten, D.K., Miller, J.H., Nachtigall, P.E., Richardson, W.J., Thomas, J.A., Tyack, P.L., 2007. Marine mammal noise exposure criteria: initial scientific recommendations. Aquatic Mammals 33 (4), 412-522.

Tintoré, J.D., La Violette, P.E., Blade, I., Cruzado, A., 1988. A study of an intense density front in the eastern Alboran Sea: the Almeria-Oran Front. J. Phys. Oceanogr. 18, 1384-1397.

Tyack, P.L., Johnson, M., Aguilar Soto, N., Sturlese, A., Madsen, P.T., 2006. Extreme diving of beaked whales. J. Exp. Biol. 209, 4238-4253.

Van Houwelingen, J.C., Le Cessie, S., 1990. Predictive value of statistical models. Stat Med. 9, 1303-1325.

Waring, G.T., Hamazaki, T., Sheenan, D., Wood, G., Baker, S., 2001. Characterization of beaked whale (Ziphiidae) and sperm whale (Physeter macrocephalus) summer habitat in shelf-edge and deeper waters off the northeast US. Mar. Mamm. Sci. 17 (4), 703-717.

Wimmer, T., Whitehead, H., 2004. Movements and distribution of northern bottlenose whales, Hyperoodon ampullatus, on the Scotian Slope and in adjacent waters. Can. J. Zool. 82, 1782-1794.

Woodward, F.I., Cramer, W., 1996. Plant functional types and climatic change: introduction. J. Veg. Sci. 7, 306-308.

Wright, A.J. et al., 2011. Size matters: management of stress responses and chronic stress in beaked whales and other marine mammals may require larger exclusion zones. Mar. Pollut. Bull. 63 (1-4), 5-9.

Zimmer, W.M.X., Pavan, G., 2008. Context driven detection/classification of Cuvier's beaked whale (Ziphius cavirostris). In: New Trends for Environmental Monitoring Using Passive Systems. IEEE Proc. ISBN 978-1-4244-2815-1. doi:10.1109/PASSIVE.2008.4786992. .

Zimmer, W.M.X., Tyack, P.L., 2007. Repetitive shallow dives pose decompression risk in deep-diving beaked whales. Mar. Mamm. Sci. 23 (4), 888-925.

Zimmer, W.M.X., Johnson, M.P., Madsen, P.T., Tyack, P.L., 2005. Echolocation clicks of free-ranging Cuvier's beaked whales (Ziphius cavirostris). J. Acoust. Soc. Am. 117 (6), 3919-3927.

Zimmer, W.M.X., Harwood, J., Tyack, P.L., Johnson, M.P., Madsen, P.T., 2008. Passive acoustic detection of deep-diving beaked whales. J. Acoust. Soc. Am. 124 (5), 2823-2883.

Zimmermann, N.E., Kienast, F., 1999. Predictive mapping of alpine grasslands in Switzerland: species versus community approach. J. Veg. Sci. 10, 469-482. 